\title{
Moisture Sources for Precipitation and Hydrograph Components of the Sutri Dhaka Glacier Basin, Western Himalayas
}

\author{
Ajit T. Singh *, Waliur Rahaman, Parmanand Sharma, C. M. Laluraj ${ }^{\circledR}$, Lavkush K. Patel, \\ Bhanu Pratap $\mathbb{D}$, Vinay Kumar Gaddam ${ }^{\mathbb{D}}$ and Meloth Thamban \\ ESSO-National Centre for Polar and Ocean Research, Headland Sada, Vasco-da-Gama, Goa 403804, India; \\ waliur@ncaor.gov.in (W.R.); pnsharma@ncaor.gov.in (P.S.); lalucm@ncaor.gov.in (C.M.L.); \\ lavkushpatel@ncaor.gov.in (L.K.P.); bhanu@ncaor.gov.in (B.P.); gaddam_vinay@ymail.com (V.K.G.); \\ meloth@ncaor.gov.in (M.T.) \\ * Correspondence: ajit.t.singh@gmail.com
}

Received: 26 August 2019; Accepted: 21 October 2019; Published: 26 October 2019

\begin{abstract}
Himalayan glaciers are the major source of fresh water supply to the Himalayan Rivers, which support the livelihoods of more than a billion people living in the downstream region. However, in the face of recent climate change, these glaciers might be vulnerable, and thereby become a serious threat to the future fresh water reserve. Therefore, special attention is required in terms of understanding moisture sources for precipitation over the Himalayan glaciers and the hydrograph components of streams and rivers flowing from the glacierized region. We have carried out a systematic study in one of the benchmark glaciers, "Sutri Dhaka" of the Chandra Basin, in the western Himalayas, to understand its hydrograph components, based on stable water isotopes $\left(\delta^{18} \mathrm{O}\right.$ and $\left.\delta^{2} \mathrm{H}\right)$ and field-based ablation measurements. Further, to decipher moisture sources for precipitation and its variability in the study region, we have studied stable water isotopes in precipitation samples (rain and snow), and performed a back-trajectory analysis of the air parcel that brings moisture to this region. Our results show that the moisture source for precipitation over the study region is mainly derived from the Mediterranean regions ( $>70 \%$ ) by Western Disturbances (WDs) during winter (October-May) and a minor contribution $(<20 \%)$ from the Indian Summer Monsoon (ISM) during summer season (June-September). A three-component hydrograph separation based on $\delta^{18} \mathrm{O}$ and d-excess provides estimates of ice $(65 \pm 14 \%)$, snowpack $(15 \pm 9 \%)$ and fresh snow $(20 \pm 5 \%)$ contributions, respectively. Our field-based specific ablation measurements show that ice and snow melt contributions are $80 \pm 16 \%$ and $20 \pm 4 \%$, respectively. The differences in hydrograph component estimates are apparently due to an unaccounted snow contribution 'missing component' from the valley slopes in field-based ablation measurements, whereas the isotope-based hydrograph separation method accounts for all the components, and provides a basin integrated estimate. Therefore, we suggest that for similar types of basins where contributions of rainfall and groundwater are minimal, and glaciers are often inaccessible for frequent field measurements/observations, the stable isotope-based method could significantly add to our ability to decipher moisture sources and estimate hydrograph components.
\end{abstract}

Keywords: Sutri Dhaka; Chandra Basin; Western Himalaya; hydrograph separation; stable water isotope; specific ablation

\section{Introduction}

The Himalayan-Karakorum mountain range has the largest concentration of glaciers outside the polar regions, out of which $\sim 9600$ glaciers lie in the Indian Himalayas, covering an area of 
$\sim 40,000 \mathrm{~km}^{2}$ [1]. These glaciers are the perennial source of runoff to major river systems, such as the Ganga, Brahmaputra and the Indus. These perennial rivers support more than a billion people living in the downstream region for their livelihood e.g., drinking, irrigation, industrial and sanitation [2-5]. Among all the major Himalayan river basins, the Indus Basin has the largest $\left(\sim 22,000 \mathrm{~km}^{2}\right)$ glacier extent [3]. The Ganga and the Brahmaputra River are primarily fed by monsoonal rain, whereas the Indus River receives the highest amount of water from snow and glacier melts [3,6]; the total glacier melt contribution to the Ganga, Brahmaputra and the Indus River estimated using snowmelt runoff model (SRM) are $\sim 10 \%, \sim 12 \%$ and $\sim 40 \%$, respectively [3]. Previous studies have suggested that $\sim 70 \%$ of Himalayan glaciers are receding at a faster rate, which has resulted in net loss of glacier volume $[2,7,8]$. As the Indus Basin receives its maximum runoff generated from the snow/ice-melt, it may face the most adverse effect of rising global temperatures [9], resulting in the initial rise in discharge, followed by the scarcity of freshwater supply leading to socio-economic instability in the downstream region $[2,3]$. Thus, considering a large number of Himalayan glaciers and their complex behavior and dynamics, it is imperative to have more studies and observations to improve our current knowledge and to address the pertinent questions related to moisture sources (rainfall/snowfall), snow/ice-melt contribution and their spatio-temporal variability.

Stable water isotope ratios of oxygen $\left(\delta^{18} \mathrm{O}\right)$ and hydrogen $\left(\delta^{2} \mathrm{H}\right)$, along with second order parameter, deuterium excess $\left(\mathrm{d}-\right.$ excess $\left.=\delta^{2} \mathrm{H}-8 \delta^{18} \mathrm{O}\right)$, have been widely used to trace moisture sources for precipitation, identify mixing water from various sources and to quantify their relative contributions $[10,11]$. Several isotope-based studies have been conducted in the Himalayan and polar regions to trace moisture sources and estimate the hydrograph components [12-23]. Moisture sources for precipitation over the central and eastern Himalayas are primarily derived from the Indian Summer Monsoon (ISM) during June-September, while moisture sources to the western Himalayas are predominantly derived from the Mediterranean region due to Western Disturbances (WDs) during winter (October-May) [6,24]. A previous study based on stable water isotopes shows that the WDs contribute the maximum $(>70 \%)$ to the total annual precipitation in the Kashmir valley (western Himalayas), which is more than the Indian Summer Monsoon (ISM) $(<30 \%)$ [15]. In contrast, a study in the Parbati Basin, western Himalayas, shows that WDs contribute a maximum up to $30 \%$ to the annual precipitation [17]. These reports clearly indicate large spatial variability in annual precipitation over the western Himalayas, particularly during the WDs.

Several studies have been conducted to estimate the contribution of snow and glacier melts in the Himalayan regions. A model-based water balance approach shows that the snow and glacier melt contribution to the Beas River at Pandoh Dam, western Himalayas, contributes $\sim 35 \%$ to the annual flow [25]. On the contrary, another study based on a stable isotopes study suggests that the snow/glacier melt contribution to the Beas River, Western Himalaya, is up to 50\% [12]. A similar study in the Parbati River, a major tributary of the Beas River, has reported that glacier melt contributes up to $\sim 44 \%( \pm 15 \%)$ [17]. A model-based water balance approach for other Himalayan rivers like the Sutlej, Ganga and the Chenab, estimates the annual snow and glacier melt contributions up to $\sim 60 \%$ (at Bhakra Dam), 28\% (at Devpryag), and $\sim 49 \%$ (at Akhnoor), respectively [26,27]. Another isotope-based study reported up to $\sim 32 \%$ contribution of snow and glacier melts to the Ganga River [28]. Such diverging results of glacier melt contributions for the Himalayan rivers could be due to the differences in the methods employed, sampling strategies, such as sampling frequency and locations (distance from glacier), uncertainty in constraining the glacier and snow melts end members, differences in defining terminologies such as glacier, snow and ice-melts, and local influences due to the diverse topography and variable climate regimes. Further, underlying assumptions involved in various methods have not been tested in these basins, and this therefore has resulted in large uncertainty and differences in the estimates $[29,30]$.

It should be noted that the relative contribution of snow and ice-melts can be better constrained at the head-ward region of the glaciated catchment, since the contribution of precipitation and subsurface water increases substantially in the downstream region. A recent isotope-based study near the 
snout of the Gangotri Glacier (Upper Ganga Basin) have reported snow, glacier melts and direct runoff contributions of about 59.6, 36.8 and 3.6\%, respectively [31]. Another study based on stable water isotope $\left(\delta^{18} \mathrm{O}\right)$ and Electrical Conductivity $(\mathrm{EC})$ has estimated contributions of supraglacial melt $(\sim 65 \%)$ and subglacial melt $(\sim 35 \%)$ from the Chhota Shigri Glacier [32]. Furthermore, few attempts have been made to validate the isotope-based precipitation source and hydrograph separation of snow/ice-melts. Therefore, to provide a baseline data for understanding moisture sources for precipitation, and to estimate the hydrograph components (snow and ice-melts) of stream flow during the peak ablation period, we have carried out a systematic study of a benchmark glacier (Sutri Dhaka) in the Chandra Basin, western Himalayas. We have employed two independent methods for the hydrograph component estimates, i.e. the stable water isotope method and field-based specific accumulation/ablation measurements. Similarly, we have also deciphered moisture sources for precipitation over the study region using stable water isotopes, which is further corroborated with the back-trajectory analysis of air parcels.

\section{Study Area}

The Sutri Dhaka Glacier catchment $\left(32^{\circ} 22^{\prime} 49^{\prime \prime} \mathrm{N}\right.$ and $\left.77^{\circ} 33^{\prime} 05^{\prime \prime} \mathrm{E}\right)$ falls in the Chandra basin of the Western Himalayan region (Figure 1) [33,34]. This glacier is a clean type glacier (C-type) with less than $5 \%$ of total debris cover $[34,35]$. The total watershed area of the Sutri Dhaka Glacier is $\sim 42 \mathrm{~km}^{2}$, of which the glacier occupies an area of $\sim 20 \mathrm{~km}^{2}$, covering approximately $50 \%$ of the total watershed. The glacier elevation ranges from $\sim 4500 \mathrm{~m}$ a.s.l. near the snout to an elevation of $\sim 6000 \mathrm{~m}$ a.s.l at the bergschrund, with a mean length of about $11 \mathrm{~km}$ (Figure 1) [34,35]. A meltwater stream flows from the snout of the Sutri Dhaka Glacier in a south-east direction for $\sim 3 \mathrm{~km}$ downstream and confluences with the Chandra River in the downstream region. A recent study based on remote sensing has reported that the Sutri Dhaka Glacier has shown a retreating trend from 1962 to 2013, with an annual retreat rate of $11.4 \pm 0.7 \mathrm{~m} \mathrm{a}^{-1}$ [35].

The climate in this region is dominated by long winters (November-March), followed by spring which lasts until the end of May [24]. The summer season starts at the end of May and lasts until the end of September, while October and early November mark a short autumn period [24]. The predominant precipitation occurs during winters $(>70 \%)$ compared to summer months $(<30 \%)$ [36]. The elevated Pir-Panjal range acts as an orographic barrier for the monsoonal clouds to reach the upper region of the Chandra Basin, resulting in limited rainfall during summer. However, few summer precipitation events occur in the form of drizzle. The aridity in the region is also shown by the lack of vegetation [36,37]. Since the study region comes under the rain shadow zone with high altitudinal variations due to steep topography, the local aquifer at higher altitude does not get recharged sufficiently to act as a potential groundwater reservoir for discharge at later stages [37]. A recent study by the Central Ground Water Board (CGWB) in the region has reported that the groundwater yield in the upstream regions of the Chandra Basin is less than 5 liters per second, which is meager compared to the total amount of discharge generated by the snow and ice-melts in the region [37]. Therefore, a major source of freshwater to the downstream settlement is mainly supplied by combined contribution of snow and ice-melts runoff. Thus, considering uniqueness of the study area in terms of the limited contribution of summer precipitation and groundwater contribution to the total discharge, the estimation of hydrograph components involves less complexity. 

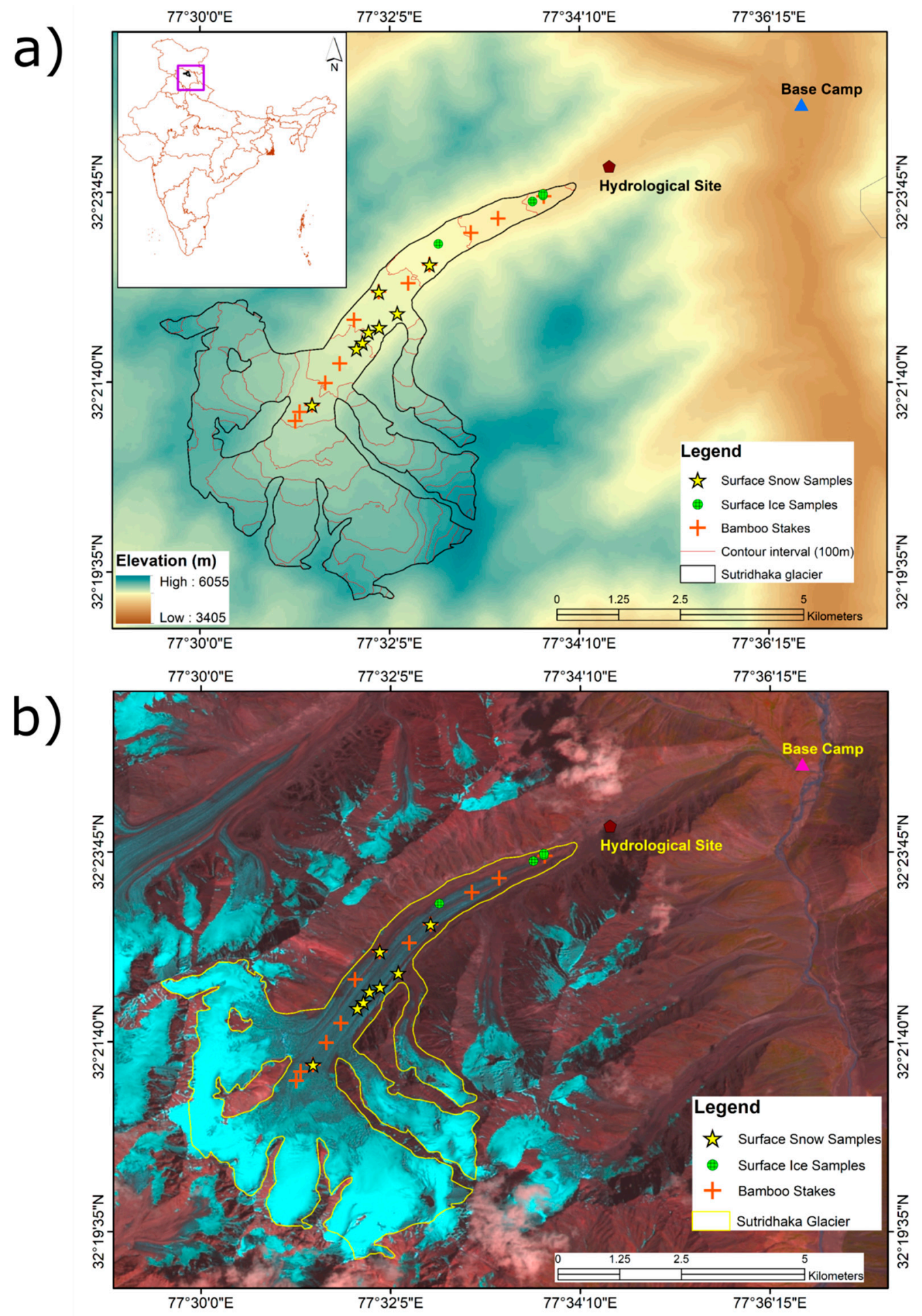

Figure 1. (a) Study area with Digital Elevation Model (DEM) derived from ASTER GDEM V2 along with sampling points; (b) Landsat 8 OLI image showing snow (light colored) and ice cover (dark colored) on the Sutri Dhaka glacier along with drainage (Image acquired on 20 August 2015).

\section{Materials and Methods}

An extensive field campaign was conducted in the Sutri Dhaka Glacier during summer-autumn (July-October) of the year 2015. Spatio-temporal samples of glacier snowpack, glacier ice, fresh snow, rainwater and stream (a combination of snow and ice-melts from the glacier) were collected systematically during the field campaign (Table 1 and Figure 1). 
An overview of the sample collection and in-situ field measurements of the glaciological and hydrological parameters on the Sutri Dhaka Glacier are shown in Figure 2, Table 1. The main tongue of the Sutri Dhaka Glacier is shown in Figure 2a. To measure the discharge of the Sutri Dhaka stream, a hydrological station was established nearly $200 \mathrm{~m}$ downstream of the present glacier snout (Figure 2b). Meltwater samples $(n=133)$ from the Sutri Dhaka stream were collected twice in a day at 10:00 hrs and 17:00 hrs (Figure 2c). Further, snowpack samples $(n=8)$ were collected from the glacier surface at various locations and certain intervals (Figure 2d), whereas fresh snowfall samples $(n=15)$ were collected from the base camp and discharge site (near snout) during a major snowfall event (20-24 September 2015). Glacial surface ice samples $(n=9)$ were strategically collected at an elevation ranging from $4550 \mathrm{~m}$ a.s.l to $4750 \mathrm{~m}$ a.s.l from the debris-covered as well as the debris-free part of the Sutri Dhaka Glacier. Precipitation samples were collected near the hydrological station (Figure 1b). However, we missed collecting samples of few rain events due to a lack of adequate logistic support. Therefore, for the present study, we have also used isotopic data of precipitation published during the same season (June to October 2015) for the Chhota Shigri Glacier, upper Chandra Basin [32]. Considering the proximity of these two glaciers, i.e., Chhota Shigri and Sutri Dhaka Glaciers, with a distance less than $15 \mathrm{~km}$, we expect similar hydro-meteorological conditions. Additionally, we conducted sampling at a similar altitude for the present study; therefore, we assume minimum changes in the isotopic characteristics of precipitation in the Sutri Dhaka and the Chhota Shigri catchments. To avoid any evaporation and atmospheric exchange with collected samples, they were filled in $20 \mathrm{~mL}$ scintillation vials without any headspace and air bubbles, and sealed immediately.

Table 1. Detailed description of end member components and stream (mixed component) sampling at the Sutri Dhaka Glacier.

\begin{tabular}{cccc}
\hline Sr. No & Sample Type & Sampling Time & No. of Samples (n) \\
\hline 1 & Glacier snowpack & 1 July 2015 & 5 \\
& & 17 October 2015 & 3 \\
2 & Fresh Snow & 21-24 September 2015 & 15 \\
3 & Glacier Ice & 1 July 2015 & 9 \\
4 & Sutri Dhaka Stream & 7 July 2015 to 9 October 2015 & 133 \\
5 & Rainwater at Sutri Dhaka & 7 July 2015 to 9 October 2015 & 9 \\
\hline
\end{tabular}

Discharge of the Sutri Dhaka stream was measured using the area-velocity method [38]. Wooden floats and Flow tracker (Son Tek Flowtracker, Son Tek, San Diego, CA, US) were used to determine the velocity of the stream. Excessive velocities, depth, boulder movement in the bed of stream and the floating drift of the instrument prohibited us from using the SonTek flow tracker during high flow. Therefore, our SonTek flow tracker measurements were only conducted during low flow conditions which showed a similar velocity reading to the float-based velocity measurement with an accuracy better than $\pm 10 \%$. Depth profiles were measured using a metal gauge. To estimate daily discharge, daily gauge measurements were conducted at 10:00 Hrs (low flow) and 17:00 Hrs (high flow), and a level versus discharge relationship was established. The mean of high and low flow was considered as a daily mean discharge [33]. Since the bed topography of high mountainous streams are unstable, and the surface velocity of the stream is higher than bed velocity, the obtained discharge value was multiplied with a factor of 0.84 to estimate the discharge [38]. The meteorological parameters, i.e., temperature and relative humidity $(\mathrm{RH} \%)$ were measured continuously using a temperature sensor (RHT-20, Extech, Waltham, MA, US) installed at the Sutri Dhaka Glacier ( $\sim 5000 \mathrm{~m}$ a.s.l). Due to a technical problem with our rain gauge instrument installed at our study site, we could not measure precipitation during the field campaign.

Therefore, we have used precipitation data measured at the base camp of an adjacent glacier; the Chhota Shigri Glacier, located $\sim 15 \mathrm{~km}$ away from the study region using an Automatic Weather Station (AWS) with accuracy better than $1 \%$. 


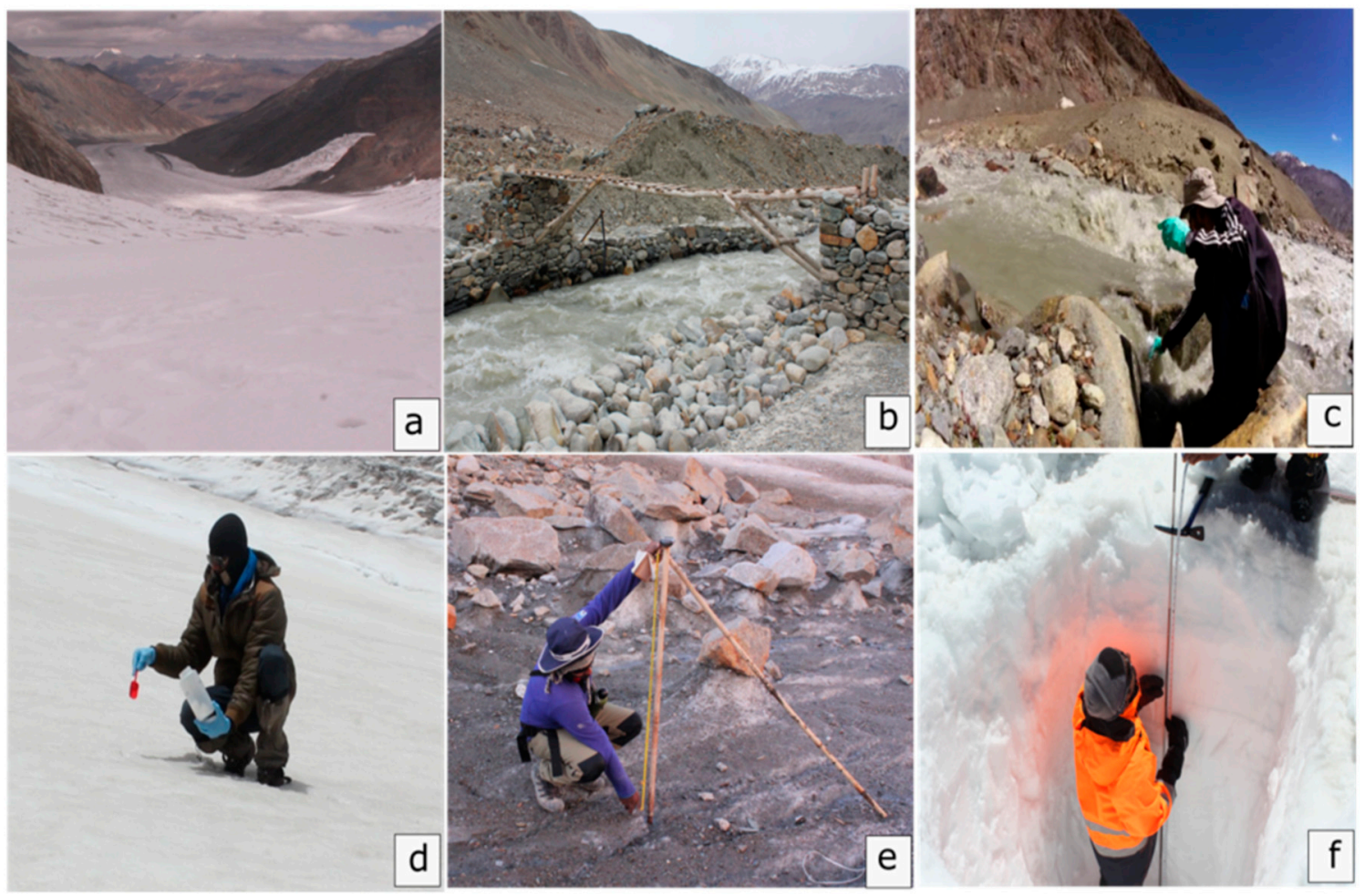

Figure 2. Fieldwork on the Sutri Dhaka Glacier and catchment: (a) Downstream synoptic view of the Sutri Dhaka Glacier showing the accumulation and ablation zone; (b) hydrological observation site; (c) meltwater sampling; (d) snowpack sampling; (e) stakes coordination and measurements; (f) snow pit excavation and density measurements.

All collected snow, ice, rain and meltwater samples were analyzed for ${ }^{2} \mathrm{H} /{ }^{1} \mathrm{H}$, and ${ }^{18} \mathrm{O} /{ }^{16} \mathrm{O}$ ratio using OA-ICOS laser absorption spectroscopy (LGR, Triple Isotope Water Analyzer (TIWA-45EP), Los Gatos Research (LGR) Process Automation, Mountain View, CA, USA) at the National Centre for Polar and Ocean Research, Goa, India. The Analyzer uses LGR's Off-axis ICOS technology, a fourth-generation cavity ring down spectroscopy (CRDS) technique [39], which employs an optical cavity to greatly enhance spectral absorption and enable us to achieve the fastest and highest precision measurements of $\delta^{18} \mathrm{O}$ and $\delta^{2} \mathrm{H}$. The isotopic ratios are reported in the standard $\delta$-notation with relative to VSMOW-SLAP [40] and expressed as

$$
\delta(\%)=\frac{\left(\mathrm{R}_{\text {sample }}-\mathrm{R}_{\text {standard }}\right)}{\mathrm{R}_{\text {standard }}} \times 1000
$$

where $\mathrm{R}$ represents either the ${ }^{18} \mathrm{O} /{ }^{16} \mathrm{O}$ or ${ }^{2} \mathrm{H} /{ }^{1} \mathrm{H}$ ratio. The overall accuracy of $\delta^{2} \mathrm{H}$ and $\delta^{18} \mathrm{O}$ measurements are better than $\pm 0.18 \%$ o and $\pm 0.07 \%$, respectively, based on the known value of a laboratory standard with respect to V-SMOW-SLAP with six injections per samples. To understand the source of the precipitation in the study region and a better identification of end-member for hydrograph separation, d-excess $\left(\mathrm{d}\right.$ - excess $\left.=\delta^{2} \mathrm{H}-8 \delta^{18} \mathrm{O}\right)$ was calculated for all samples using $\delta^{2} \mathrm{H}$ and $\delta^{18} \mathrm{O}$ [41]. The relationship between $\delta^{2} \mathrm{H}$ and $\delta^{18} \mathrm{O}$ in precipitation was defined using the least square regression method [10].

Meltwater of the Sutri Dhaka stream is predominantly sourced from two components (snow and ice-melts) and therefore a simple two component hydrograph separation using single tracer $\left(\delta^{18} \mathrm{O}\right)$ can be used to determine the snow and ice-melt contributions to the meltwater stream [42].

However, it was difficult to constrain the end member value of $\delta^{18} \mathrm{O}_{\text {snow }}$ as a single component because they undergo several stages of post-depositional processes such as evaporation, sublimation 
and repetitive melting-freezing cycles, which could cause large isotope fractionation. In earlier studies, based on modeling and field evidences, it was suggested that $\delta^{18} \mathrm{O}$ values in a snowpack could be heavier up to 3 to $5 \%$ o than the fresh snow due to preferential removal of lighter isotopes in melts resulting in large uncertainty in hydrograph separation [42,43]. Therefore, in the present study, fresh snow (isotopically depleted) and snowpack (isotopically enriched) were considered as two separate components of snow, covering the entire spectrum of snow contribution, and a three-component hydrograph separation was performed to estimate the contribution of fresh snow, snowpack and ice-melt to the Sutri Dhaka stream.

In the case of three-component hydrograph separations based on a geochemical and isotope mass balance approach, at least two tracers are required. Using $\delta^{18} \mathrm{O}$ along with electrical conductivity (EC), silica $\left(\mathrm{SiO}_{2}\right)$ and chloride $\left(\mathrm{Cl}^{-}\right)$are among the most common tracers, and are widely used for three-component hydrograph separation (Klauss and McDonnell, 2013). However, they have limitations in separating snow and ice-melt contributions to glacier stream since the $\mathrm{EC}, \mathrm{SiO}_{2}$ and other dissolved solutes may get enriched due to water-rock interaction. In order to circumvent this problem, several studies have suggested that $\delta^{18} \mathrm{O}$ and d-excess can be successfully used to trace the contribution of hydrological components $[44,45]$.

Thus, we have used $\delta^{18} \mathrm{O}$ and d-excess as tracers in constraining the end members for a three-component hydrograph separation of the Sutri Dhaka stream. Since the contribution of rainwater to total discharge is insignificant, we have not considered it as a major hydrograph component in our calculations $[32,36,37,46]$. The equation for three-component hydrograph separation can be written as follows [44].

$$
\mathrm{Q}_{\mathrm{St}}=\mathrm{Q}_{\mathrm{i}}+\mathrm{Q}_{\mathrm{o}}+\mathrm{Q}_{\mathrm{n}}
$$

where $Q_{i}, Q_{o}$ and $Q_{n}$ are the contribution of ice-melts, old snow (snowpack), fresh snow to the Sutri Dhaka stream discharge $\left(\mathrm{Q}_{\mathrm{st}}\right)$.

$$
\begin{gathered}
1=f_{i}+f_{o}+f_{n} \\
\delta_{s t}=\delta_{i} \cdot f_{i}+\delta_{o} \cdot f_{o}+\delta_{n} \cdot f_{n}
\end{gathered}
$$

$\delta_{\mathrm{st}}, \delta_{\mathrm{i}}, \delta_{\mathrm{o}}$ and $\delta_{\mathrm{n}}$ and are $\delta^{18} \mathrm{O}$ for the stream, ice, snowpack and fresh snow respectively.

$$
d_{s}=d_{i} \cdot f_{i}+d_{o} \cdot f_{o}+d_{n} \cdot f_{n}
$$

$d_{s t}, d_{i}, d_{o}$ and $d_{n}$ are $d$-excess tracer for the stream, ice, snowpack and fresh snow respectively.

$$
\begin{gathered}
Q_{i}(\%)=\frac{\left(d_{s t}-d_{n}\right)\left(\delta_{o}-\delta_{n}\right)-\left(d_{o}-d_{n}\right)\left(\delta_{s t}-\delta_{n}\right)}{\left(d_{i}-d_{n}\right)\left(\delta_{o}-\delta_{n}\right)-\left(d_{o}-d_{n}\right)\left(\delta_{i}-\delta_{n}\right)} \times 100 \\
Q_{o}(\%)=\frac{\left(d_{s t}-d_{n}\right)}{\left(d_{o}-d_{n}\right)} \times 100-\frac{\left(d_{i}-d_{n}\right)}{\left(d_{o}-d_{n}\right)} \times Q_{i} \\
Q_{n}(\%)=100-Q_{i}-Q_{o}
\end{gathered}
$$

The ice-melt, snowpack and fresh snow contributions to the total discharge were calculated using Equations (6)-(8) respectively.

The total snow and ice-melt contributions were also estimated using a field-based ablation measurement of total snow and ice during the study period. In order to measure snow and ice ablation of the Sutri Dhaka Glacier, a network of 12-15 ablation stakes of $\sim 6-10 \mathrm{~m}$ deep was installed along the center line of glacier surface at different altitudes, following the standard protocols published elsewhere [35,47]. To measure net ablation during the subsequent ablation period (July-October 2015), stakes were installed at the end of the ablation season i.e., September 2014. The lengths of the exposed stakes were measured on a monthly basis from 5 July to 5 October 2015 for the summer ablation measurements (Figure 2e). Net ablation was estimated based on the ice cover loss at each point multiplied with the density of ice. Ice density was measured at nine different locations in the ablation 
zone. The average density of $870 \pm 10 \mathrm{~kg} \mathrm{~m}^{-3}$ based on nine measurements at different locations was used in ice ablation estimates in terms of water equivalent. For the snowmelt contribution, we have measured winter snow accumulation (4 July 2015) and annual/residual snow accumulation (September-October 2015) by excavating four snow pits followed by density measurements at different altitudes of the glacier surface (Figure $2 \mathrm{f}$ ). The measured thickness was linearly extrapolated to the higher reaches (5350-6050 $\mathrm{m}$ a.s.l.) to accommodate the total snow accumulation in the glacierized zone. Total snowmelt during the study period (July to October 2015) was then calculated by subtracting winter accumulation from residual accumulation. A simple transient snow line (TSL)-snow pit method was also used to measure snow ablation. The snow line was measured before the study was conducted (27 June 2015), and at the maximum snowline elevation (30 August 2015), using Landsat 8 OLI satellite imagery [48]. Since the mean accumulated snow was known from snow pit estimates, the total snow cover area ablation estimated using the TSL method was multiplied with respective snow pit volume ( $m$ w.e.) and the total snow volume ablation for the study period were estimated [48]. Due to inaccessibility to the site for sampling during the spring season, our study was limited to the peak summer period (July-October 2015), when maximum melting occurs.

Further, to understand moisture sources for precipitation over the study region throughout the year, we performed monthly back trajectory analysis of air parcels reaching the sites using the NOAA HYSPLIT model together with a reanalysis model output from the Global Data Assimilation System (GDAS) dataset [49]. Four days back trajectory analysis was performed for all months of the year 2015. All trajectories were initialized at $1500 \mathrm{~m}$ above the surface because most of the water vapor in the atmosphere travel within 0-2 km above ground level [49]. Subsequently, trajectories obtained for each day for the respective months were clustered using Trajstat to obtain the mean monthly trajectories [50]. Similarly, four days back-trajectory analysis to capture major precipitation events was plotted using the Global Data Assimilation System (GDAS) dataset at different altitudes (100, 1500 and $2000 \mathrm{~m}$ AGL) and also using HYSPLIT online simulation developed by Air Resources Laboratory, NOAA [51,52].

\section{Results and Discussion}

\subsection{Hydro-Meteorological Characteristics of the Sutri Dhaka Stream}

Meteorological parameters play a significant role in controlling the glacier melt dynamics [3]. Temporal variations in air temperature, relative humidity, precipitation and discharge of the Sutri Dhaka Glacier are shown in Figure 3 and data provided in supplementary excel sheet. The discharge of the Sutri Dhaka stream during the study period varied between $0.2 \mathrm{~m}^{3} \mathrm{~s}^{-1}$ to $20 \mathrm{~m}^{3} \mathrm{~s}^{-1}$ with a mean of $8.9 \mathrm{~m}^{3} \mathrm{~s}^{-1}$ (Figure 3a). The discharge during the study period increased from early July with rising temperatures and reached its peak by the end of July. The daily mean temperature during the study period ranged from -15.3 to $16.1{ }^{\circ} \mathrm{C}$ with a mean of $9.1^{\circ} \mathrm{C}$ (Figure 3b). Similarly, daily mean RH varied from $34.8 \%$ to $99.9 \%$ with a mean of $59.8 \%$ (Figure 3c). The highest daily mean discharge $\left(20 \mathrm{~m}^{3} \mathrm{~s}^{-1}\right)$ and temperature $\left(16.2^{\circ} \mathrm{C}\right)$ were observed on 15 July 2015. A gradual declining trend in temperature and discharge were observed in the months of August, September and October. A significant correlation $\left(\mathrm{R}^{2}=0.83, \mathrm{n}=63 ; p<0.05\right)$ was observed between the daily mean discharge and temperature (Figure 3$)$, suggesting a dominant control of temperature on discharge. This relationship implies a $\sim 9 \%$ increase in daily mean discharge per degree rise in daily mean air temperature. This finding confirms that as the temperature in the Himalayan region increases, it would lead to an initial rise in discharge due to an increase in glacier melt, followed by a drop in runoff and reduction in the glacierized area [53]. A total of $\sim 110 \mathrm{~mm}$ of precipitation was recorded during the study period, of which two major precipitation events occurred on 12 July $(20 \mathrm{~mm})$ and on 23 September $(52 \mathrm{~mm})$ in the form of snow which account for $\sim 66 \%$ of total precipitation during the study period (Figure $3 \mathrm{~d}$ ). 


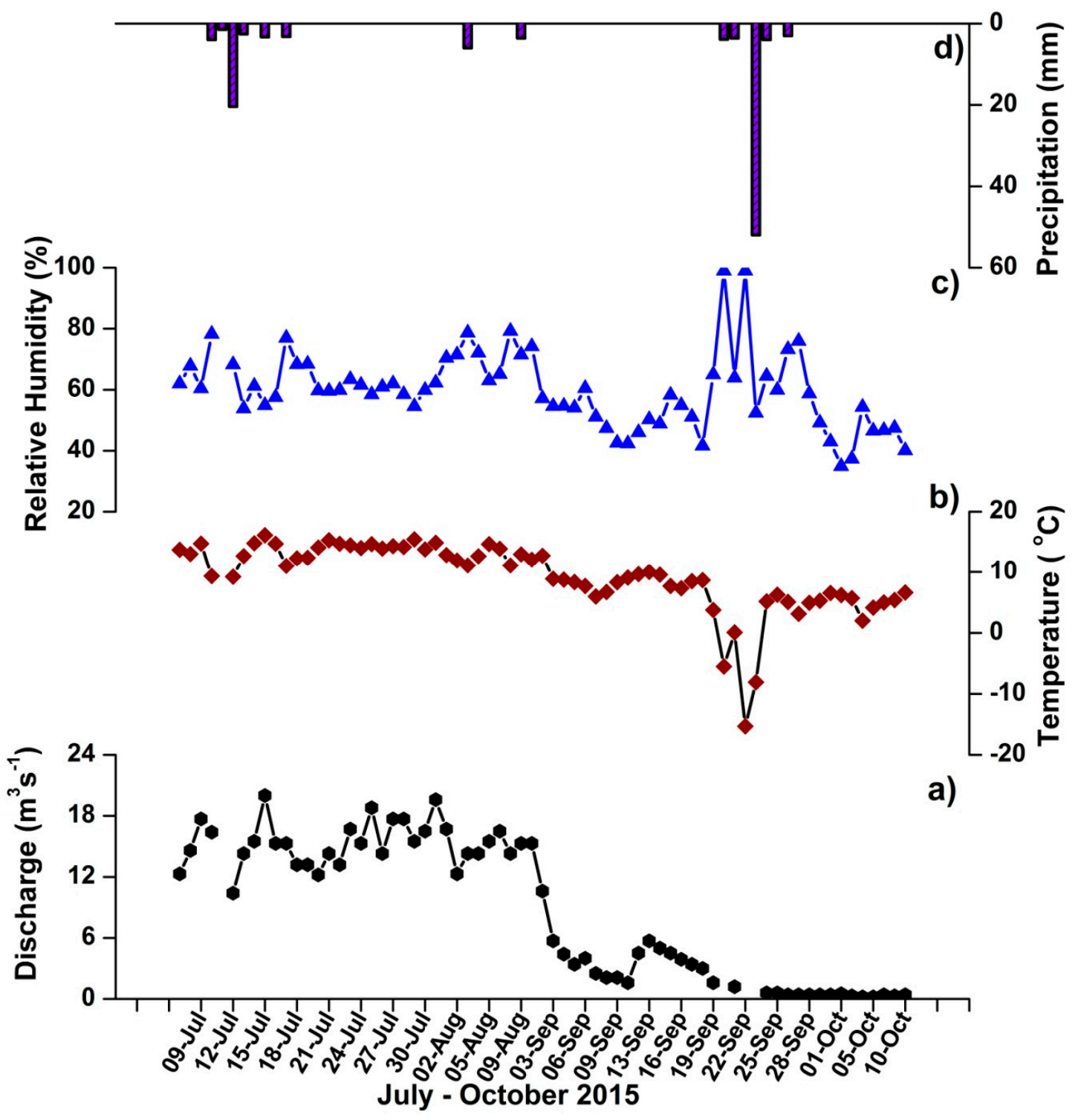

Figure 3. Daily distribution of the observed (a) Discharge; (b) Daily average temperature; (c) daily mean of Relative Humidity (RH\%) (d) Daily mean precipitation measured during the study period.

\subsection{Stable Isotope Characteristics and Its Relationship with Discharge}

Details of samples and their isotopic characteristics are mentioned in Table 2 and data provided in supplementary excel sheet. $\delta^{18} \mathrm{O}$ and $\delta^{2} \mathrm{H}$ measured in rainwater samples varied from $-13.9 \%$ o to $-5.4 \%$ o and $-107.2 \%$ o to $-32.5 \%$ o with a mean of $-11.2 \%$ ond $-81.6 \%$, respectively. Similarly, $\delta^{18} \mathrm{O}$ in rainwater samples collected from the Chhota Shigri Glacier showed a median value of $-11.2 \%$ o [32]. The fresh snow samples collected at the base camp and hydrological station during the snowfall events, 20-24 September 2015, showed depleted $\delta^{18} \mathrm{O}$ values compared to that of the snowpack. Enrichment of $\delta^{18} \mathrm{O}$ in snowpack could be the result of isotopic fractionation between the melts and the snowpack. As isotopically-depleted snow starts melting, it leads to the removal of depleted meltwater that results in a heavier residual snowpack [30]. Glacier ice samples showed a narrower range compared to snow samples. $\delta^{18} \mathrm{O}$ and $\delta^{2} \mathrm{H}$ in ice samples ranged from $-15.7 \%$ o to $-11.7 \%$ o (mean $-13.6 \pm 1.2 \%$ ) and $-106.3 \%$ o to $-73.2 \%$ o (mean $-91.2 \pm 10.4 \%$ o) respectively. The $\delta^{18} \mathrm{O}$ and $\delta^{2} \mathrm{H}$ values in stream draining from the Sutri Dhaka Glacier varied from $-15.7 \%$ o to $-13.3 \%$ o (mean $-14.4 \pm 0.5 \%$ o) and $-108.9 \%$ o to $-91.4 \%$ o (mean $-98.5 \pm 3.8 \%$ o), respectively. 
Table 2. $\delta^{18} \mathrm{O}, \delta^{2} \mathrm{H}$ and d-excess values of rain, fresh snow, snowpack, glacier ice and meltwater of the Sutri Dhaka Glacier catchment.

\begin{tabular}{|c|c|c|c|c|c|c|c|c|c|c|}
\hline \multirow[t]{2}{*}{ Parameter } & \multicolumn{2}{|c|}{ Rain (n = 9) } & \multicolumn{2}{|c|}{$\begin{array}{l}\text { Fresh Snow } \\
\quad(n=15)\end{array}$} & \multicolumn{2}{|c|}{$\begin{array}{c}\text { Snow Pack } \\
(n=8)\end{array}$} & \multicolumn{2}{|c|}{ Ice $(n=9)$} & \multicolumn{2}{|c|}{$\begin{array}{c}\text { Sutri Dhaka } \\
\text { Stream }(n=133)\end{array}$} \\
\hline & Mean & $1 \mathrm{SD}$ & Mean & $1 \mathrm{SD}$ & Mean & $1 \mathrm{SD}$ & Mean & $1 \mathrm{SD}$ & Mean & $1 \mathrm{SD}$ \\
\hline$\delta^{18} \mathrm{O}(\%$ \% $)$ & -11.2 & 3.2 & -20.3 & 0.2 & -10.1 & 0.7 & -13.6 & 1.25 & -14.4 & 0.5 \\
\hline$\delta^{2} \mathrm{H}(\%$ o $)$ & -81.6 & 26.5 & -145.8 & 1.4 & -67.7 & 5.5 & -91.2 & 10.4 & -98.5 & 3.9 \\
\hline d-excess (\%o) & 8.1 & 5.4 & 17.1 & 0.7 & 13.2 & 2.5 & 18 & 1.4 & 17.1 & 0.9 \\
\hline
\end{tabular}

The mean d-excess values of snow, ice, meltwater and rainwater are provided in Table 2. The deuterium excess (d-excess) values for all samples range from $0.47 \%$ o to $20.2 \%$ o with a mean of $16.5 \pm 2.7 \%$ o. Lower d-excess values were observed in rain events, whereas higher values were observed in snowfall events and the snowpack. A similar trend was also reported in precipitation events collected from the Chhota Shigri Glacier during the same period [32]. Glacier ice samples showed the highest d-excess values among all followed by the Sutri Dhaka stream. The higher d-excess $(>12 \%$ o) of fresh snow, old snow, ice and Sutri Dhaka stream suggest Western Disturbance (WD) as their common moisture source, derived from the Mediterranean regions [19].

\subsection{Local Meteoric Water Line (LMWL), d-Excess and Moisture Sources for Precipitation}

In an earlier study, a Local Meteoric Water Line (LMWL) plotted based on precipitation samples collected from the Chhota Shigri shows a slope of 7.9 and an intercept of 21.4 [32] (Figure 4). This slope is similar to the Global Meteoric Water Line (GMWL) within their uncertainty $\left(\delta^{2} \mathrm{H}=8 * \delta^{18} \mathrm{O}+10\right)$, suggesting their marine origin, while a higher intercept indicates mixing of air moisture masses derived from different sources. The overall least square regression line or best fit line constructed based on precipitation event samples collected from the Sutri Dhaka Glacier shows that the slope $(7.4 \pm 0.4)$ is similar to the Chhota Shigri Glacier with lower intercept (2.0 \pm 5.4$)$ (Figure 4). The lower intercept of the Sutri Dhaka Glacier could be because of a smaller number of representative samples for the entire season. Few precipitation events at the Sutri Dhaka Glacier fall close to GMWL, suggesting a contribution of ISM and the effect of sub-cloud evaporation during the precipitation events (Figure 4).

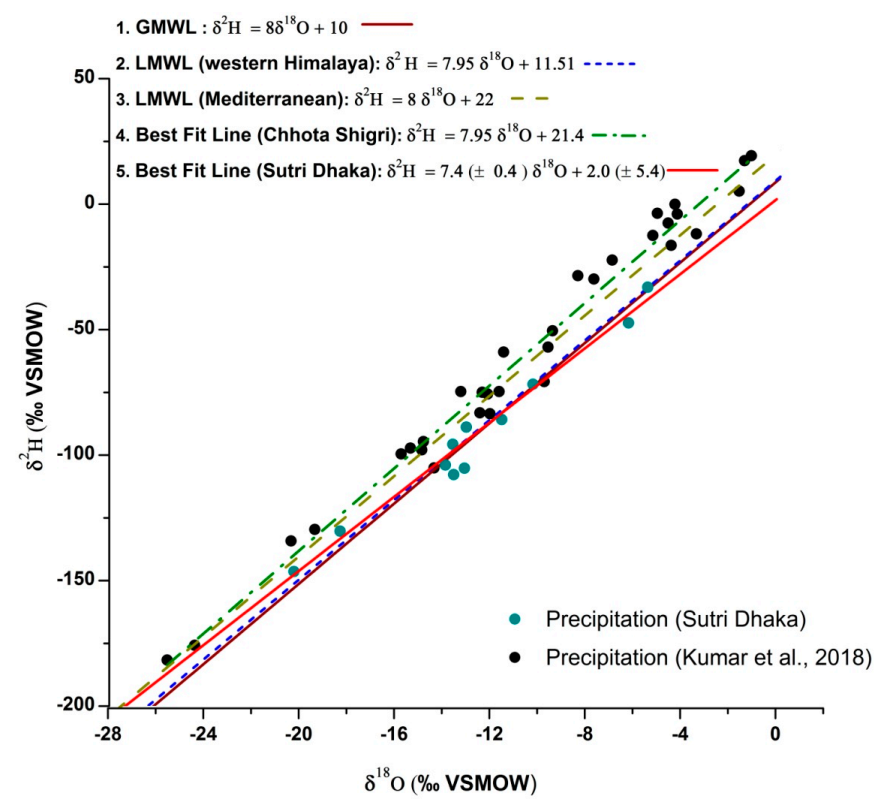

Figure 4. The regression lines in the cross plot $\left(\delta^{2} \mathrm{H}\right.$ vs. $\left.\delta^{18} \mathrm{O}\right)$ for precipitation samples from the Sutri Dhaka Glacier and Chhota Shigri Glacier are compared with Local Meteoric Water Line (LMWL) of the Western Himalaya, Mediterranean region and Global Meteoric Water Line (GMWL) (Kumar et al., 2018). 
$\delta^{2} \mathrm{H}$ vs. $\delta^{18} \mathrm{O}$ plot for fresh snow, snowpack, glacier ice, rain is shown in Figure 5, and the slope and intercept of each regression line are also provided in Table 3. The ice samples collected from the Sutri Dhaka Glacier show a similar slope $(8.1 \pm 0.4)$ and intercept $(20.3 \pm 5.6)$ similar to the Chhota Shigri and the Mediterranean region. Lower slope $(6.5 \pm 1.2)$ and intercept $(-1.2 \pm 12.3)$ were reported for the snowpack, indicating the effect of non-equilibrium fractionation leading to isotopic enrichment of the snowpack due to a preferential removal of lighter isotopes in melts during sublimation processes $[13,19]$. Unlike snowpack, fresh snow samples showed slightly higher slope (7.3 \pm 0.2$)$ and intercept of $(4.1 \pm 5.1)$, while rainwater showed a slope of $(7.7 \pm 0.6)$ and intercept of $(6.1 \pm 7.1)$. The Sutri Dhaka stream showed a slope of $(7.1 \pm 0.2)$ with an intercept of $(5 \pm 2.7)$. The slopes of the regression lines of all components (snow, ice, rain, stream) are similar within their uncertainty, which confirms that they have common moisture sources [20]. However, the intercepts of all components are highly variable, suggesting the effect of secondary isotope fractionation processes during precipitation events and melting processes. The slopes and intercepts of LMWL in the Himalayan region varies significantly, indicating variable sources of precipitation and environmental conditions, such as temperature of condensation, local moisture recycling and amount of sub-cloud evaporation during precipitation (Table 3) [10,54-56].

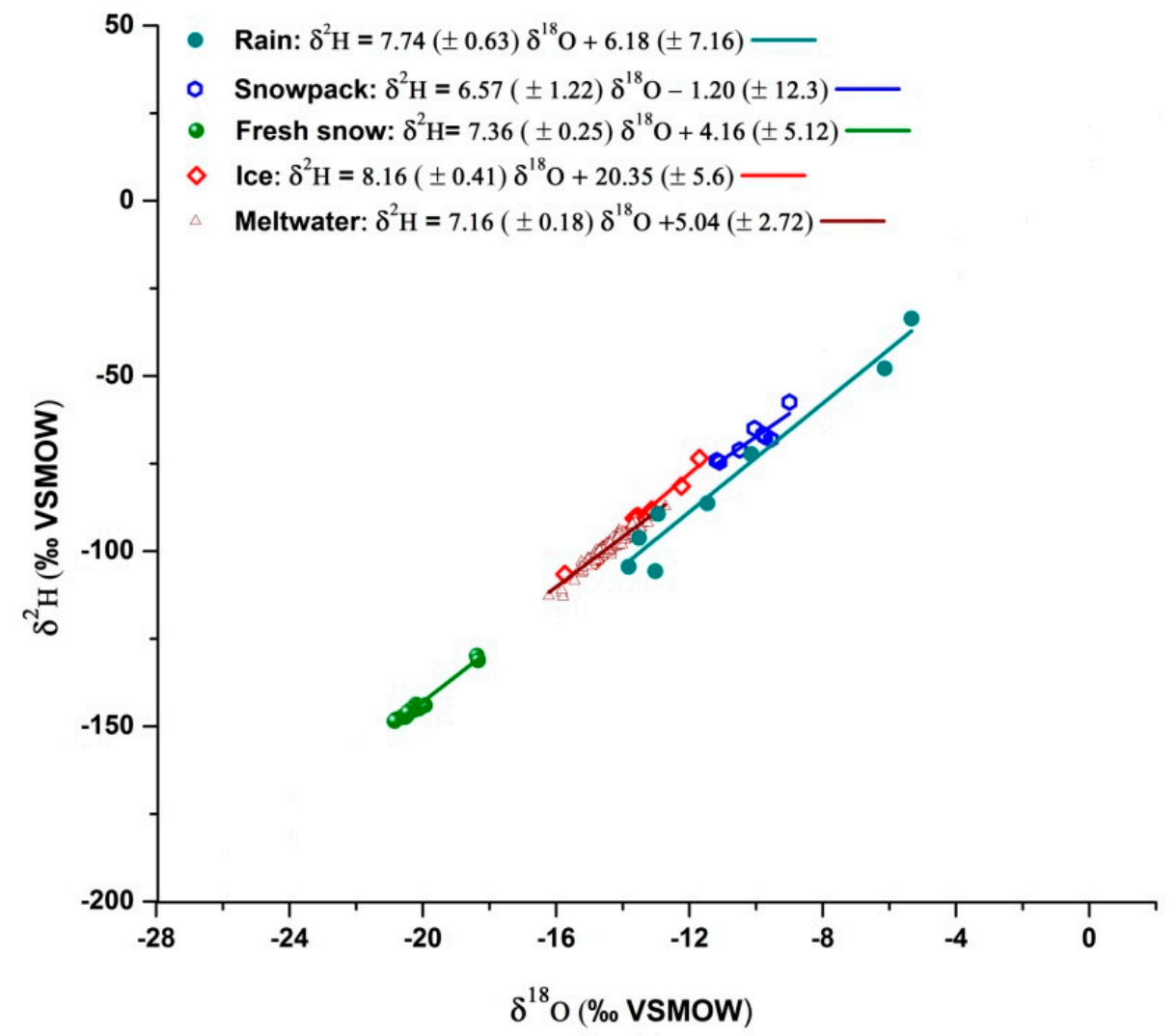

Figure 5. The stable isotope regression plot $\left(\delta^{2} \mathrm{H}\right.$ vs. $\left.\delta^{18} \mathrm{O}\right)$ for Rain, Fresh snow, Snowpack, Ice and daily Sutri Dhaka Glacier stream. 
Table 3. Compilation of local meteoric water lines (LMWL) of various studies carried out in the Himalayan regions for Rain (R), Fresh Snow (SF), Snowpack/firn (SP), Glacier ice (GI) and meltwater stream or River (SR).

\begin{tabular}{|c|c|c|c|c|c|c|c|}
\hline \multirow{2}{*}{$\begin{array}{l}\text { Glacier/Region } \\
\text { Sutri Dhaka } \\
\text { Glacier }\end{array}$} & Latitude & Longitude & Altitude (m) & LMWL & $\mathbf{R}^{2}$ & $\mathrm{n}$ & Reference \\
\hline & $32^{\circ} 22^{\prime} 49^{\prime \prime} \mathrm{N}$ & $77^{\circ} 33^{\prime} 05^{\prime \prime} \mathrm{E}$ & $4500-6200$ & $\begin{array}{c}\delta^{2} \mathrm{H}=6.5( \pm 1.2) * \delta^{18} \mathrm{O}-1.2 \\
( \pm 12.3)(\mathrm{SP}) \\
\delta^{2} \mathrm{H}=7.3( \pm 0.2) * \delta^{18} \mathrm{O}+4.1 \\
\quad( \pm 5.1)(\mathrm{SF}) \\
\delta^{2} \mathrm{H}=8.1( \pm 0.4) * \delta^{18} \mathrm{O}+20.3 \\
\quad( \pm 5.6)(\mathrm{GI}) \\
\delta^{2} \mathrm{H}=7.1( \pm 0.2) * \delta^{18} \mathrm{O}+5.04 \\
\quad( \pm 2.7)(\mathrm{SR}) \\
\delta^{2} \mathrm{H}=7.7( \pm 0.6) * \delta^{18} \mathrm{O}+6.18 \\
\quad( \pm 7.1)(\mathrm{R})\end{array}$ & 0.94 & $\begin{array}{l}17 \\
11 \\
65 \\
9\end{array}$ & $\begin{array}{l}\text { Present } \\
\text { Study }\end{array}$ \\
\hline \multirow[t]{2}{*}{$\begin{array}{l}\text { Chota Shigri } \\
\text { Glacier }\end{array}$} & $32^{\circ} 16^{\prime} 48^{\prime \prime} \mathrm{N}$ & $77^{\circ} 34^{\prime} 48^{\prime \prime} \mathrm{E}$ & $4050-6263$ & $\delta^{2} \mathrm{H}=7.8^{*} \delta^{18} \mathrm{O}+25(\mathrm{SP})$ & 0.99 & 10 & [32] \\
\hline & & & & $\begin{array}{l}\delta^{2} \mathrm{H}=6.3 * \delta^{18} \mathrm{O}+3.6(\mathrm{GI}) \\
\delta^{2} \mathrm{H}=7.9 * \delta^{18} \mathrm{O}+21.4(\mathrm{R})\end{array}$ & 0.76 & 15 & \\
\hline \multirow[t]{2}{*}{$\begin{array}{l}\text { Chorabari } \\
\text { Glacier }\end{array}$} & $30^{\circ} 46^{\prime} 20.58^{\prime \prime} \mathrm{N}$ & $79^{\circ} 02^{\prime} 59.381^{\prime \prime} \mathrm{E}$ & $4400-6200$ & $\delta^{2} \mathrm{H}=8.1 * \delta^{18} \mathrm{O}+24.1(\mathrm{SF})$ & 0.9 & 45 & [16] \\
\hline & & & & $\begin{array}{l}\delta^{2} \mathrm{H}=7.7^{*} \delta^{18} \mathrm{O}+21.2(\mathrm{GI}) \\
\delta^{2} \mathrm{H}=6.51 * \delta^{18} \mathrm{O}-0.0(\mathrm{SR}) \\
\delta^{2} \mathrm{H}=7.98 * \delta^{18} \mathrm{O}+16.8(\mathrm{R})\end{array}$ & $\begin{array}{c}1 \\
0.8 \\
0.98\end{array}$ & $\begin{array}{c}13 \\
116 \\
35\end{array}$ & \\
\hline \multirow[t]{2}{*}{$\begin{array}{l}\text { QS and Glacier } \\
\text { no.12, T.P }\end{array}$} & $39^{\circ} 26.4^{\prime \prime} \mathrm{N}$ & $96^{\circ} 32.5^{\prime \prime} \mathrm{E}$ & $4260-5481$ & $\delta^{2} \mathrm{H}=8.2^{*} \delta^{18} \mathrm{O}+21.68(\mathrm{SP})$ & 0.95 & & [57] \\
\hline & & & & $\begin{array}{c}\delta^{2} \mathrm{H}=7.7^{*} \delta^{18} \mathrm{O}+15.7(\mathrm{GI}) \\
\delta^{2} \mathrm{H}=7.8 * \delta^{18} \mathrm{O}+16.8(\mathrm{R})\end{array}$ & $\begin{array}{l}0.83 \\
0.95\end{array}$ & & \\
\hline $\begin{array}{l}\text { Kashmir Drass } \\
\text { and Ladakh } \\
\text { Zanskar }\end{array}$ & $32^{\circ} 50^{\prime}-34^{\circ} 18^{\prime} \mathrm{N}$ & $74^{\circ} 45^{\prime}-78^{\circ} 20^{\prime} \mathrm{E}$ & $3250-4345$ & $\begin{array}{c}\delta^{2} \mathrm{H}=8.2 * \delta^{18} \mathrm{O}+23.8(\mathrm{SR}) \\
\delta^{2} \mathrm{H}=6.6^{*} \delta^{18} \mathrm{O}-1(\mathrm{SR}) \\
\delta^{2} \mathrm{H}=9.5 * \delta^{18} \mathrm{O}+38.7(\mathrm{GI})\end{array}$ & & & [19] \\
\hline \multirow[t]{2}{*}{$\begin{array}{l}\text { Jammu and } \\
\text { Kashmir }\end{array}$} & $33^{\circ} 20^{\prime}-34^{\circ} 15^{\prime} \mathrm{N}$ & $74^{\circ} 30^{\prime}-75^{\circ} 35^{\prime} \mathrm{E}$ & $1592-3248$ & $\delta^{2} \mathrm{H}=7.6^{*} \delta^{18} \mathrm{O}+11.8(\mathrm{R})$ & & & {$[13,14,58]$} \\
\hline & & & & $\begin{array}{l}\delta^{2} \mathrm{H}=7.6^{*} \delta^{18} \mathrm{O}+15(\mathrm{SP}) \\
\delta^{2} \mathrm{H}=6.7 * \delta^{18} \mathrm{O}+8.1 \text { (SR) }\end{array}$ & $\begin{array}{l}0.95 \\
0.87\end{array}$ & $\begin{array}{c}39 \\
155\end{array}$ & \\
\hline $\begin{array}{l}\text { Nam Co Basin, } \\
\text { T.P }\end{array}$ & $30^{\circ} 39^{\prime \prime} \mathrm{N}$ & $90^{\circ} 38^{\prime \prime} \mathrm{E}$ & 4730 & $\begin{array}{c}\delta^{2} \mathrm{H}=8.3 * \delta^{18} \mathrm{O}+7.8(\mathrm{SP} / \mathrm{GI}) \\
\delta^{2} \mathrm{H}=7.6^{*} \delta^{18} \mathrm{O}-2.30(\mathrm{SR})\end{array}$ & 0.98 & & [59] \\
\hline
\end{tabular}

The $\delta^{18} \mathrm{O}$ values of the precipitation samples collected during the major precipitation events which occurred on 12 July and 20-24 September 2015 show depleted values and higher d-excess (Figure 6a-c).

A significant reduction in discharge after the major precipitation events coincides with temperature drop (Figure 6a). As the fresh snow after major precipitation events melts it also results in depleted $\delta^{18} \mathrm{O}$ in stream water with higher d-excess (Figure 6a-c).

Several studies have shown that the higher d-excess $(>12 \%$ o) in precipitation was generally related to the precipitation sourced from the high evaporation and low humidity regions, such as the Mediterranean, Caspian and Black seas through the western disturbances $[19,58]$. Monthly back-trajectory analysis of air parcels also reveals that the moisture parcel is primarily derived from the Mediterranean Sea and the Persian Gulf during the winter months due to WDs. Similarly, the moisture sources during the summer months are supplied by WDs with a minor contribution by ISM (Figure 7a). Few studies have also been carried out to decipher moisture sources for precipitation over other parts of the Himalayan regions using d-excess and back trajectory analysis $[12,15,16,20,28,59,60]$. However, other studies in the lower region of the western Himalayas have reported a stronger influence of ISM with high spatio-temporal variability in the sources for precipitation over the western Himalayan region $[12,17,28]$. Our event-based back trajectory analysis of the major summer precipitation events shows that the air parcel comprises both ISM and WDs origins (Figure $7 \mathrm{~b}$ ). An extensive study conducted in the western Himalayas found that the precipitation derived from WDs shows a much higher d-excess value (mean 18.9\%o) compared to that of ISM (mean 9.4\%o) [58]. Considering the higher d-excess $(>17 \%$ o) in our major precipitation event clearly indicates that they are mainly derived from the WDs. A two-component mixing model using ISM and WDs d-excess values as end members shows that more than $80 \%$ of the total precipitation is derived from WDs while the ISM contributes 
more than $20 \%$. Since the d-excess values remain constant during phase change at the time of the rainout events, we can confidently deduce that the precipitation source to the major precipitation event is predominantly derived from the WDs. Similarly, a study conducted at a similar duration of our study at the Chhota Shigri Glacier in the Chandra Basin, western Himalayas, also reported higher d-excess values during heavy summer precipitation events, attributing to WDs being the precipitation source [32].
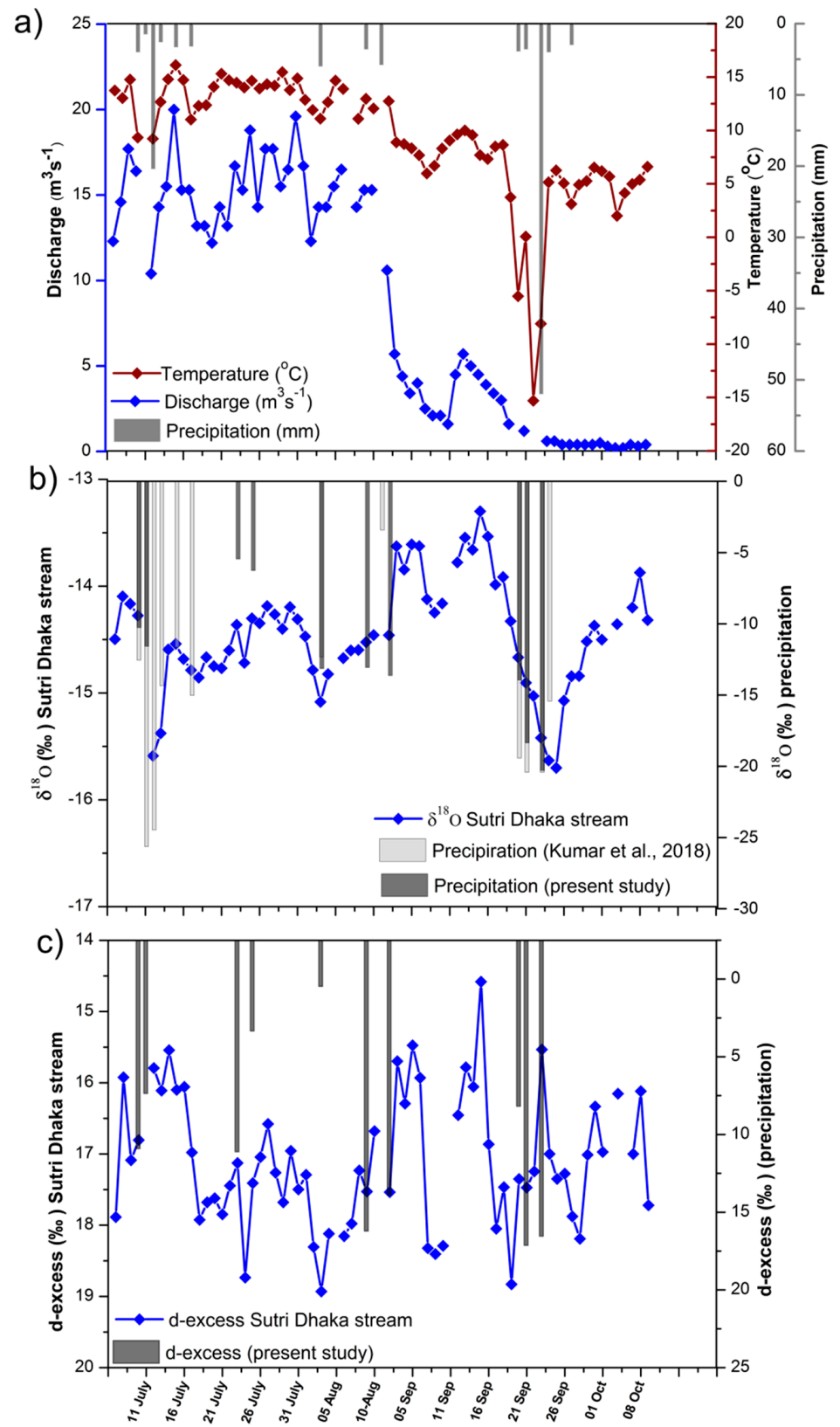

Figure 6. Time series of the measured parameters; (a) discharge and precipitation at the study region during the study period along with their associated (b) $\delta^{18} \mathrm{O} \%$ and (c) d-excess of the stream water and precipitation at the Sutri Dhaka Glacier (present study), and the Chhota Shigri Glacier (Kumar et al., 2018) Upper Chandra Basin.

A positive correlation $\left(R^{2}=0.3, n=33 ; p<0.05\right)$ was observed between discharge and $\delta^{18} \mathrm{O}$ values of the stream water samples during July to mid-August, which was further improved during September and early October $\left(R^{2}=0.57, \mathrm{n}=31 ; p<0.05\right)$ (Figure 8). Variable correlations between discharge and $\delta^{18} \mathrm{O}$ values suggest that the initial stream water was sourced from both snow as well as 
ice-melt waters with variable contributions and as summer progressed, snow contribution got reduced with an increasing contribution from ice-melts to stream discharge. However, it is noteworthy to observe a significant declining trend in discharge and $\delta^{18} \mathrm{O}$ values after intense precipitation events on 12 July 2015 and 20-24 September 2015 (Figure 8). A significant drop in temperature, glacier melt and discharge indicates that the precipitation on the glacier occurred in the form of snow. Therefore, a major supply of meltwater contributed to the downstream region was supplied by the melting of isotopically-depleted fresh snow, which resulted in depleted meltwater.

a)

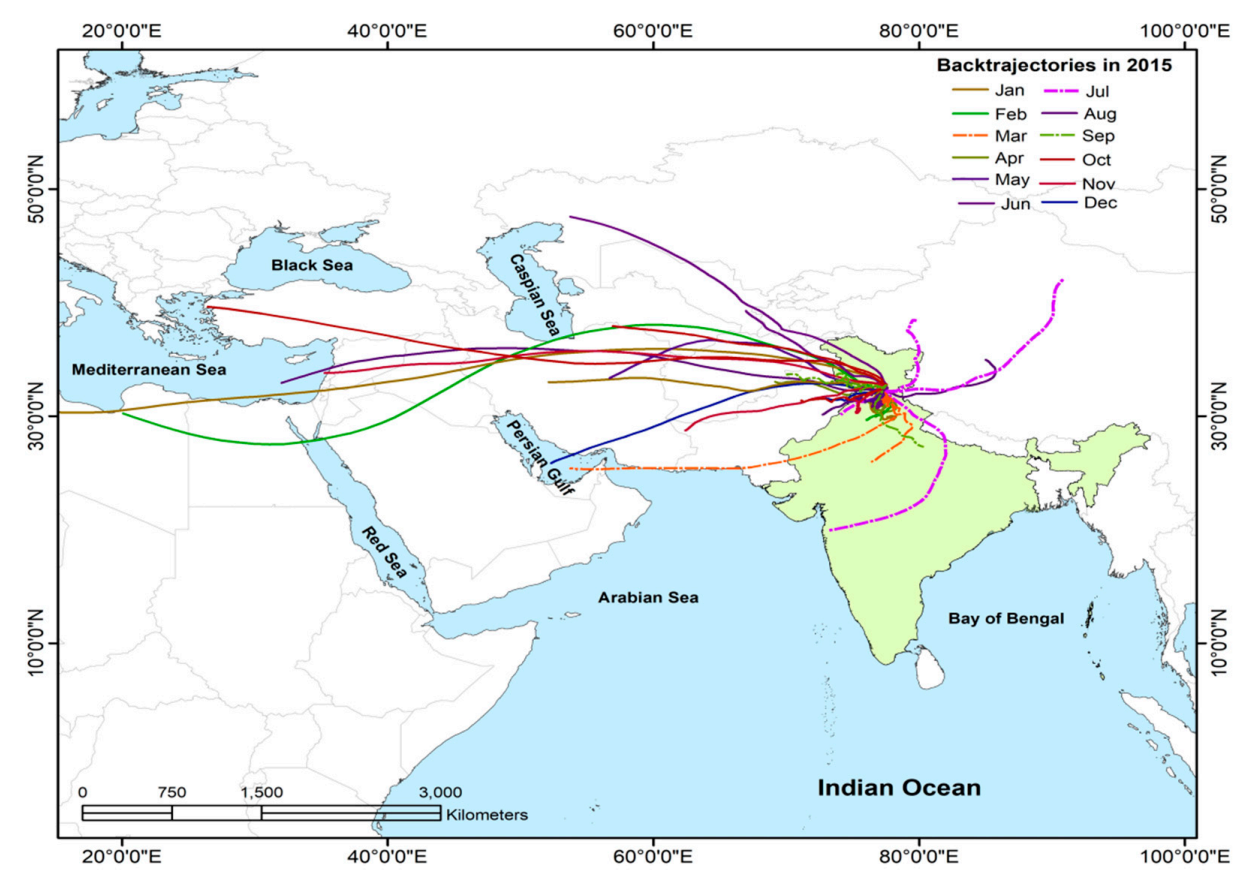

b)

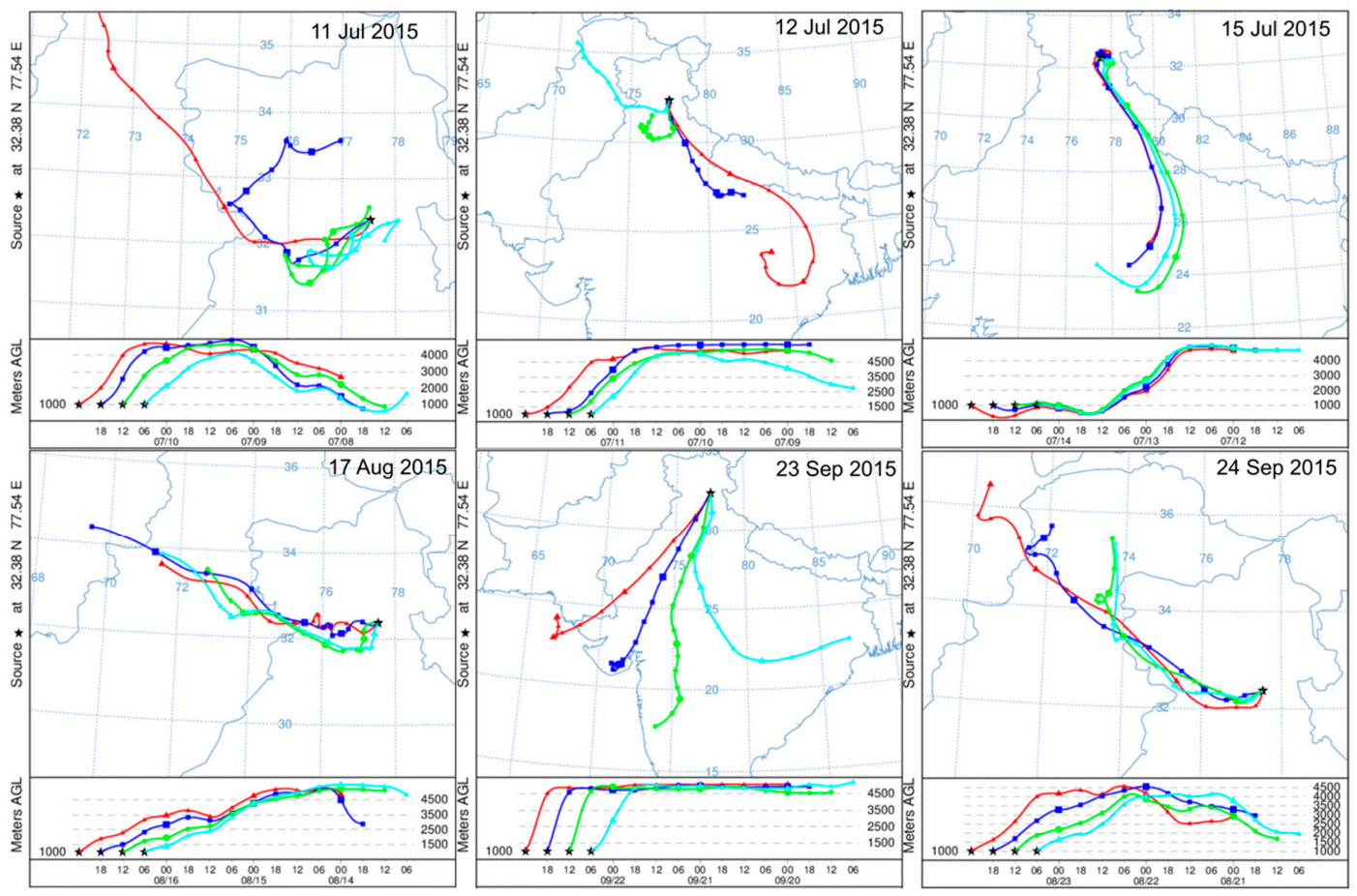

Figure 7. Back trajectory analysis at the study region (a) for entire year (January-December 2015) (b) for major precipitation events initiated at 1000, 1500 and 2000 m AGL for four days. 


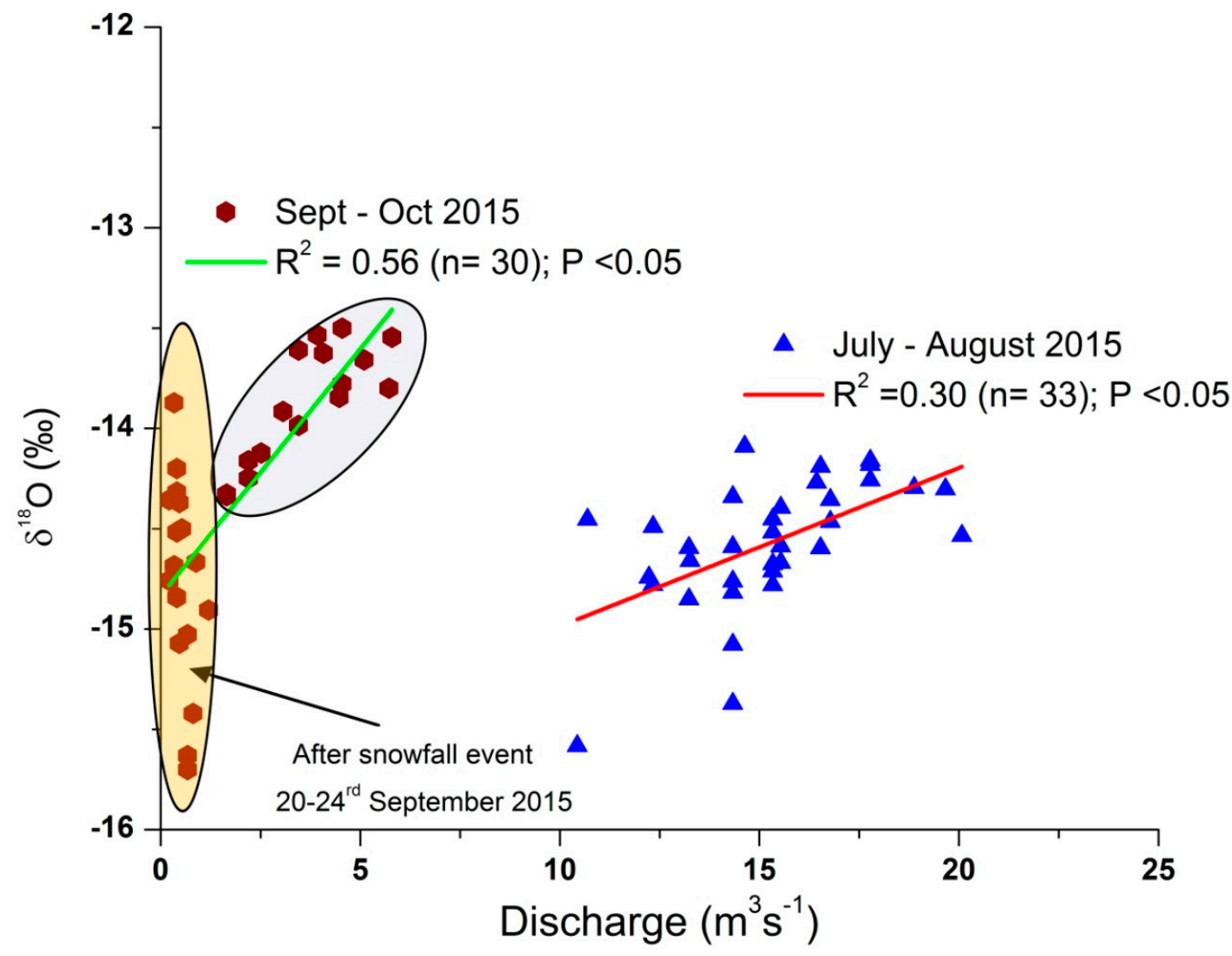

Figure 8. Relationships between $\delta^{18} \mathrm{O}$ and stream discharge during the peak ablation period (July and August) and at the end of ablation season (September and October).

\subsection{Snow and Ice-Melt Contribution to the Sutri Dhaka Stream}

\subsubsection{Hydrograph Separation}

The hydrological process can be well understood using a mixing plot (d-excess vs. $\delta^{18} \mathrm{O}$ ) $[44,45]$. Mixing plots in the present study clearly shows that the stable isotope signatures of the Sutri Dhaka stream are more close to the glacier ice-melt end member compared to snowmelt and rainwater (Figure 9). This indicates that the fresh snow on the glacier surface might undergo several stages of post-depositional processes, leading to large isotopic fractionation. 


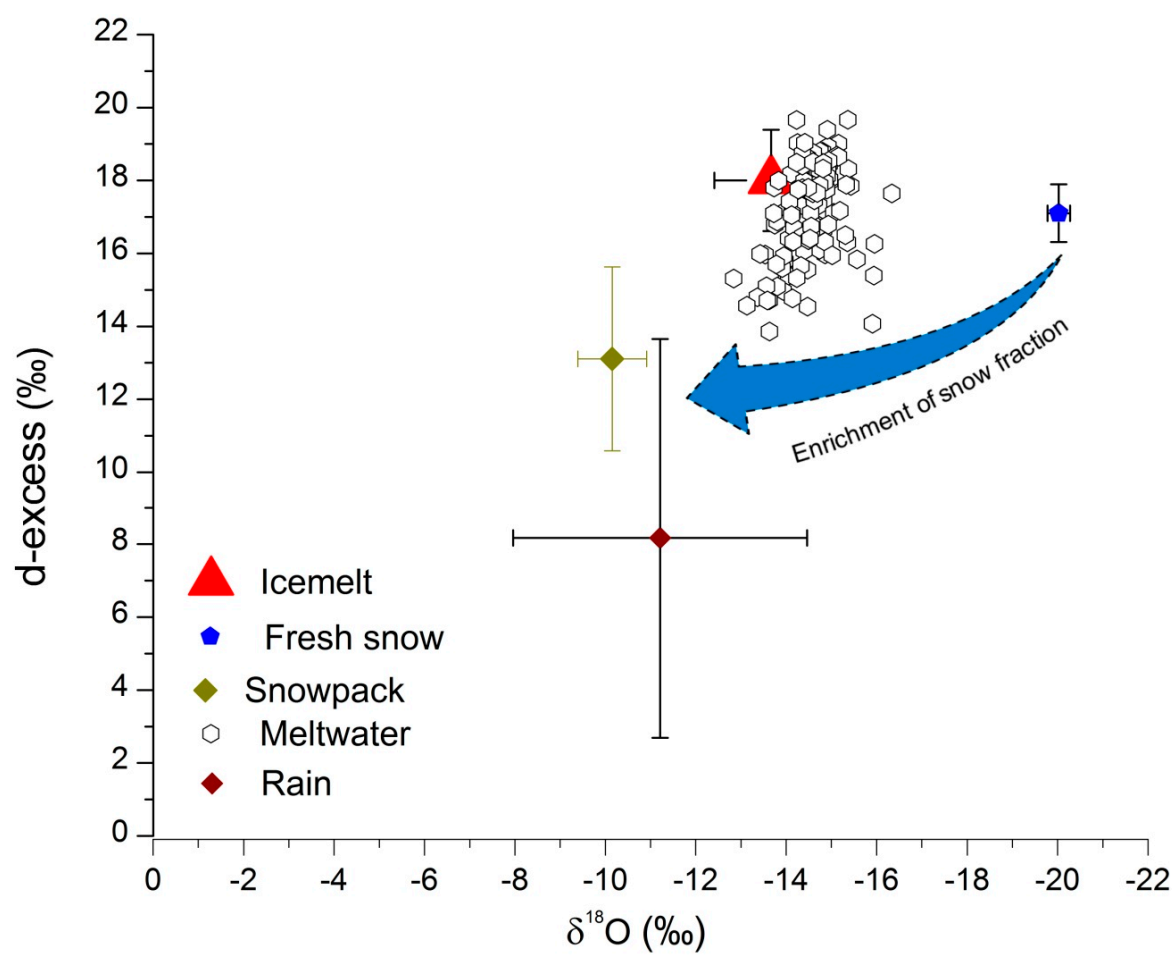

Figure 9. A mixing diagram showing d-excess vs. $\delta^{18} \mathrm{O}$ of the mean value of snow, ice and rainwater and daily stream meltwater samples. The arrow indicates the evolution of the fresh snow due to the effect of secondary processes after the precipitation.

A three-component hydrograph separation of the Sutri Dhaka stream revealed that the contribution of ice-melt, snowpack and fresh snow are $65 \pm 14,15 \pm 9$ and $20 \pm 5 \%$, respectively (Figure 10). Results of hydrograph separation suggest that the ice-melt is the dominant contributor to the Sutri Dhaka stream water during July-October. However, we observed a significant declining trend in ice-melt and an increase in fresh snow, followed by a snowpack contribution to the Sutri Dhaka stream after the major snowfall events on 12 July and 20-24 September 2015. The overall contribution from the snowmelt suggests that they are mainly derived from the isotopically-depleted snow as well as the enriched snowpack. Despite a spike in fresh snow contribution followed by a snowpack, the ice-melt remained a dominant contributor throughout the study period. A significant decline in temperature has been observed after the major snowfall event (20-24 September 2015), which significantly reduces the surface melting. Therefore, the main source of ice-melt during September and October could be from the subglacial ice-melt due to pressure melting [32]. It has been observed that by the end of September the supraglacial melting reduced substantially, and a major contribution to the stream melt water were supplied by the melting of subglacial ice [61]. 

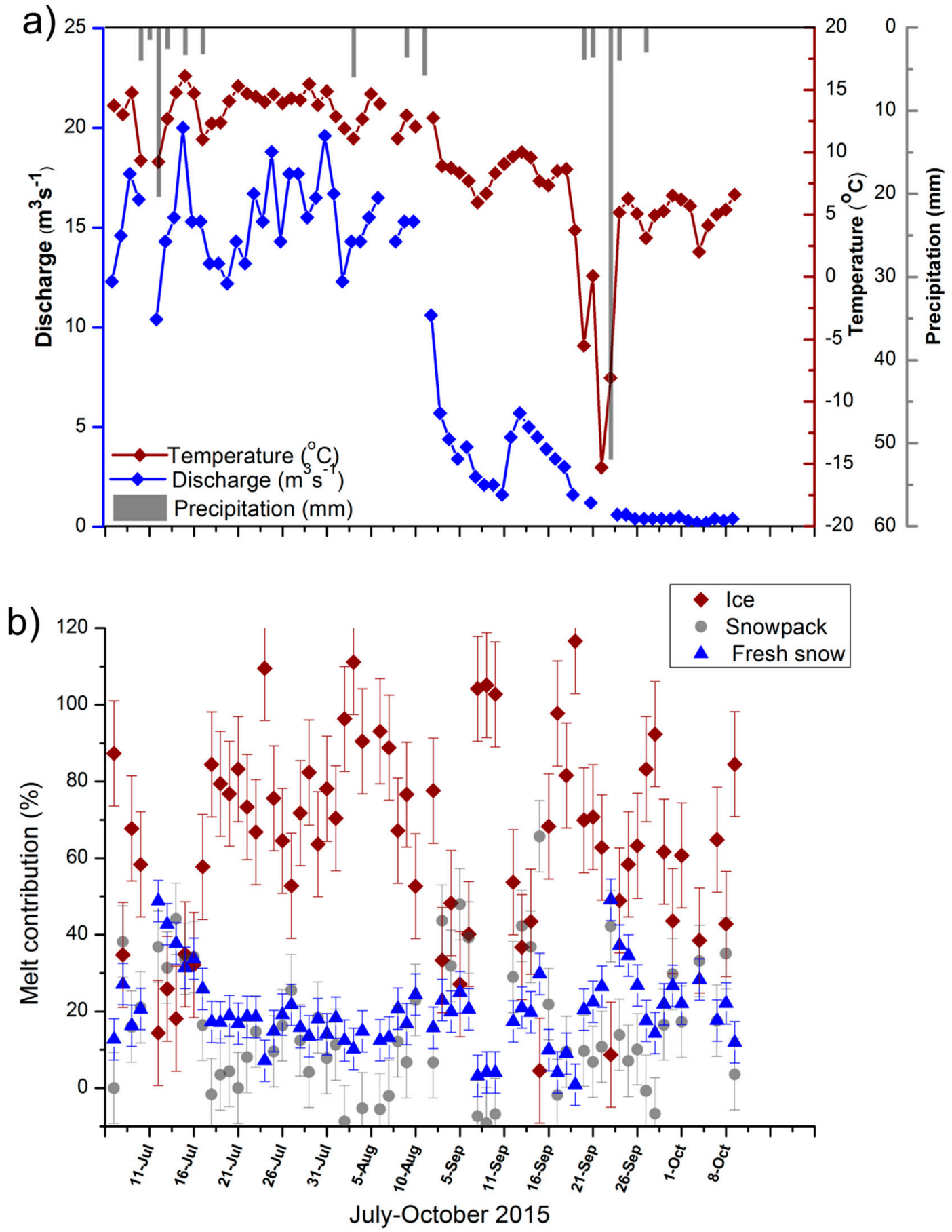

Figure 10. Hydro-meteorological characteristics of the Sutri Dhaka Glacier (a) Discharge is compared with temperature and precipitation; (b) contribution of ice-melt, snowpack and fresh snow to the Sutri Dhaka stream estimated based on three-component separation.

\subsubsection{Specific Ablation of Snow and Ice}

To validate our estimates of hydrograph separation based on stable isotope method, we have compared with the field estimates obtained from stake-based ablation and snow accumulation measurements. The estimated winter snow accumulation based on several snow-pit measurements on the glacierized area on 4 July 2015 varied from 0.24 to $1.17 \mathrm{~m}$ w.e (meter water equivalent) between the elevation ranges 4500 to $5300 \mathrm{~m}$ a.s.l. The total snow accumulation estimated for the glacierized area is $14.0 \pm 2.28 \times 10^{6} \mathrm{~m}^{3}$ w.e. 
As the summer progresses, the accumulated snow starts melting, and by the end of the ablation period most of the area ( $<5320 \mathrm{~m}$ a.s.l) becomes snow-free. At the end of the study period ( 28 September), estimation of the residual (annual) snow accumulation at $\sim 5300 \mathrm{~m}$ a.s.l was $9.04 \pm 1.8 \times 10^{6} \mathrm{~m}^{3}$ w.e (Figure 11). The depletion of snow line over the glacier surface defines the zero balance area, known as the Equilibrium Line Altitude (ELA). Based on the measurements of stakes installed on the glacier, the ELA observed at the end of the ablation season was at $5320 \mathrm{~m}$ a.s.l. To estimate the total snowmelt from 4 July to 28 September (nearly three months), the annual snow accumulation was subtracted from the winter snow accumulation. The difference between the winter accumulation and residual accumulation $(\mathrm{C} w-\mathrm{Ca})$ is $-5.0 \pm 1.0 \times 10^{6} \mathrm{~m}^{3}$ w.e., which accounts for snowmelt contribution to the stream runoff (Figure 11).

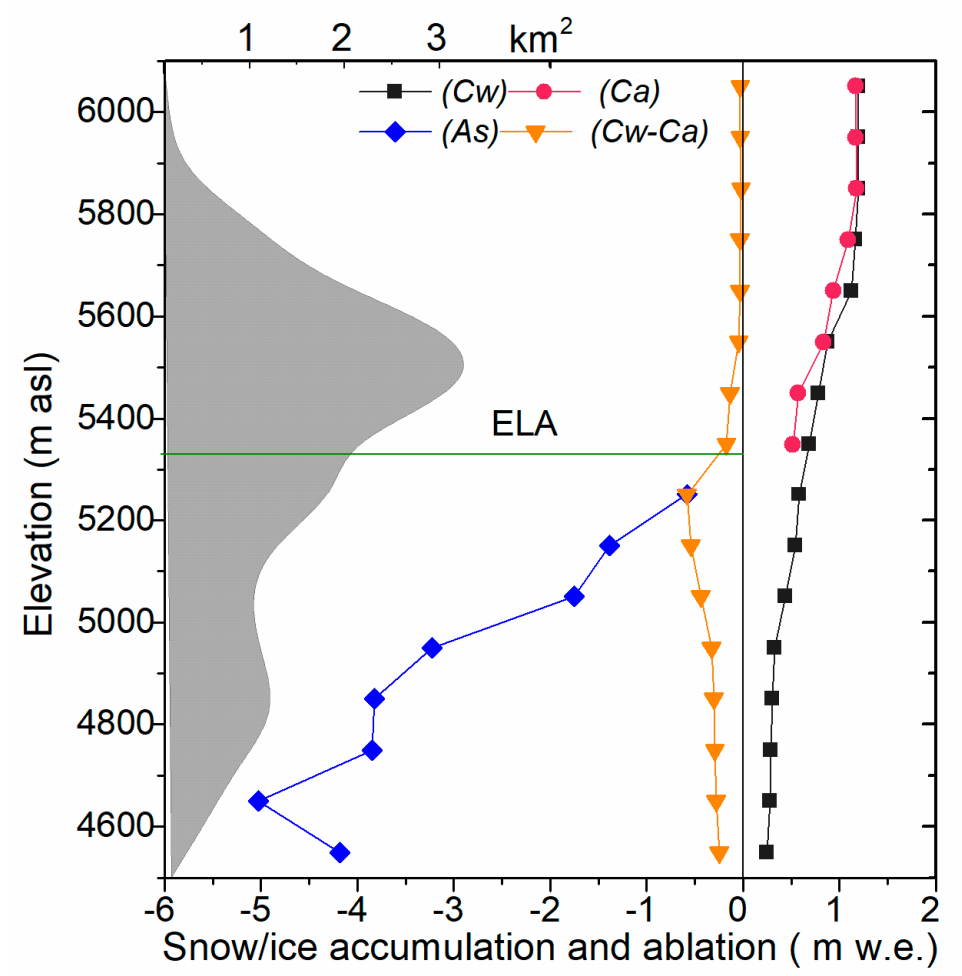

Figure 11. The observed winter snow accumulation $(C w)$, annual/residual snow accumulation $(C a)$, summer ice ablation $(A s)$ and summer snowmelt $(\mathrm{Cw}-\mathrm{Ca})$, and the area altitude distribution of Sutri Dhaka Glacier for the period of 5 July-28 September 2015.

A transient snowline on the glacier was estimated using Landsat 8 OLI images and demarcated using ASTER GDEM which was further validated with the ground control points. A transient snowline-snow pit method shows that the snowline position before the study commenced was at an altitude of $4511( \pm 46) \mathrm{m}$ a.s.l (27 June 2015) (Supplementary Figure S1). As the melting progressed, the snowline reached up to $5601( \pm 46) \mathrm{m}$ a.s.l (30 August 2015) at peak of ablation season with total snow area loss of $10.41 \mathrm{~km}^{2}$ and snow volume loss of $-5.8 \times 10^{6} \mathrm{~m}^{3}$ w.e (Figure 12). It is noteworthy to observe that the snow ablation estimate using the transient snowline-snow pit method agrees with our field-based snow ablation measurement within the range of uncertainty. As the snow cover melts, the ice becomes exposed, and starts melting with the increase in air temperature. The cumulative summer ice ablation $(A s)$ for the study period (5 July to 28 September 2015) between the elevation of 4500 to $5300 \mathrm{~m}$ a.s.l, yield a total glacier ice-melt of $-20 \pm 4 \times 10^{6} \mathrm{~m}^{3}$ w.e. Maximum ice ablation was observed at an altitude of 4600-4700 $\mathrm{m}$ a.s.l, which was reduced progressively towards higher altitude due to lower air temperature. The total cumulative melt contribution from snow and ice during this period provides an estimate of $-25 \pm 5 \times 10^{6} \mathrm{~m}^{3}$ w.e (Figure 11). Contributions of snow and ice-melt towards the production of meltwater discharge are approximately $20 \pm 4 \%$ and $80 \pm 16 \%$, respectively. 


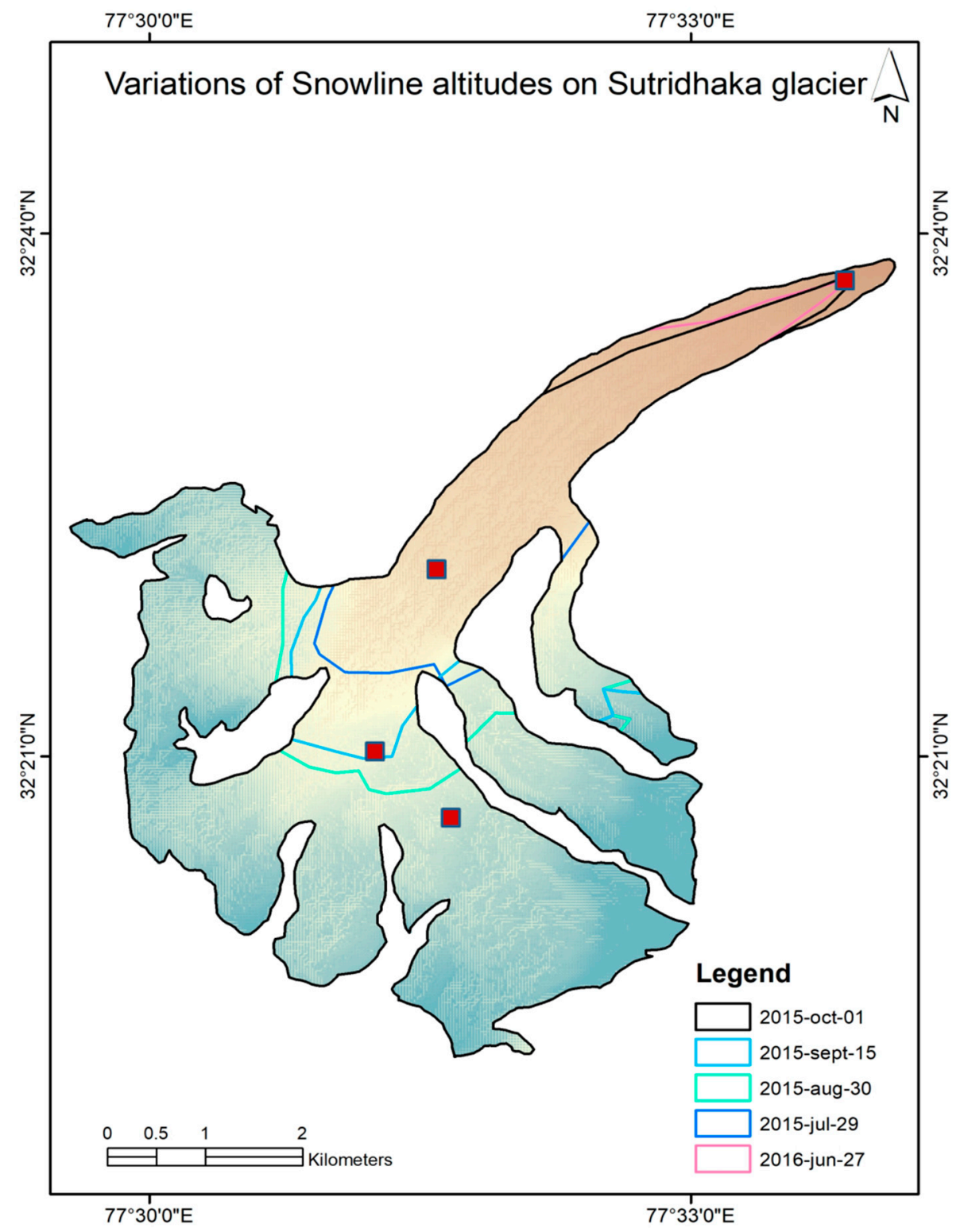

Figure 12. Transient snowline estimated using Landsat 8 OLI images of Sutri Dhaka Glacier and excavated snow pits (brown square) during the study period.

\subsubsection{Uncertainty in Hydrograph Separation Estimates}

Hydrograph separations and their quantitative assessments using the stable isotope method are often a challenging task due to a large spread on the $\delta^{18} \mathrm{O}$ values of the hydrograph components. Stable water isotope compositions of snow and ice vary spatially and temporally, which contributes to uncertainties associated with the estimates of hydrograph components $[62,63]$. Three-component hydrograph estimates are critically dependent on the end-member values of $\delta^{18} \mathrm{O}$ and d-excess and uncertainties associated with them. To better constrain the uncertainty associated with the estimates of hydrograph components based on $\delta^{18} \mathrm{O}$ and d-excess, we used a Monte Carlo error propagation method $[64,65]$. This simulation method was used to solve the Equations (7)-(9) with 50,000 iterations for each stream samples and uncertainty, with a $68 \%$ confidence interval (CI) acquired for each mixing fraction. Based on Monte Carlo simulation, the uncertainty in ice-melt, snowpack and fresh snow estimates are 14, 9 and 5\%, respectively. The overall uncertainty in each component is shown with error bars (Figure 10). 
The accuracy of specific ablation using a network of bamboo stakes and snow pits cannot be evaluated strictly, as some of the random errors in this method are unknown. Uncertainty in this method is mainly derived from glacier area estimates, stake measurements and snow depth and density measurements $[66,67]$. Based on the field data, uncertainty in glaciological field measurements has been reported to be maximum up to $\pm 20 \%[35,65]$. Therefore, in the present study, we have considered an error of $\pm 20 \%$ for specific ablation measurements.

Comparison of our hydrograph components estimates-based two independent methods i.e., the field-based ablation measurement and the stable isotope-based hydrograph method, the latter method provides $\sim 15 \%$ higher estimates of the snowmelt component. This difference arises due to an unaccounted contribution from the deposited snow over the valley slope of the glacierized area in the field-based method. However, the isotope-based method provides an estimate of an integrated average of snow and ice-melt contributions from the entire basin to the downstream. Therefore, we suggest that for basins in the upper Indus Basin, where the contribution of rainfall and groundwater are minimal, a stable isotope method can be complimentary along with the field-based ablation measurements. Further, the glaciers which are inaccessible for the field measurements, the stable isotope method could add to our ability to evaluate snow /ice-melt contribution from high altitude Himalayan glaciers.

\section{Conclusions}

The present study provides insights on the moisture sources for the precipitation and hydrograph components of the Sutri Dhaka Glacier basin in the western Himalayas during the peak ablation period in the year 2015. Stable isotope fingerprinting of moisture sources together with back trajectory analysis indicate that the moisture to the study area is predominantly derived from the Mediterranean Sea regions through the Western Disturbances (WDs). However, the major sources for the precipitation during summer are supplied by the ISM as well as WDs. A combination of stable water isotope data and field ablation measurements provide information about the dominant sources of water contributing to the stream runoff of the Sutri Dhaka as well as the major moisture sources for precipitation over the study region. Three-component hydrograph separation of the Sutri Dhaka Glacier based on stable isotope methods shows a dominant contribution of ice-melt $(65 \% \pm 14)$ to the stream discharge, followed by snowpack $(15 \% \pm 9)$ and fresh snow $(20 \pm 5 \%)$. Despite the uncertainties associated with these estimates, the results of isotope hydrograph separation are overall consistent with that of stake-based field measurements; the contribution of ice-melt and snowmelt are $80 \pm 16 \%$ and $20 \pm 4 \%$, respectively. However, the stable isotope method provides relatively more accurate estimates of hydrograph components compared to field-based ablation measurements, as it integrates over the entire catchments in the upstream of the sampling site, whereas the field-based method does not account for part of the snow component in the valley slope. Considering the limited information on the hydrograph components of the Himalayan glaciers, this study will enhance our current knowledge and understanding of hydrological processes in high altitude western Himalayan regions.

Supplementary Materials: A excel sheet containing all numerical data used for present study is available online at http://www.mdpi.com/2073-4441/11/11/2242/s1. Excel 1, Figure S1: Transient snowline estimated using Landsat 8 OLI images of Sutri Dhaka glacier during the study period.

Author Contributions: A.T.S., W.R., C.M.L., P.S. and M.T. defined the objectives of the study and the writing of the manuscript. A.T.S. collected field samples and analyzed them for the stable water isotope at Ice core laboratory. A.T.S., L.K.P. collected data in the field, and B.P. interpreted the infield ablation results. V.K.G. generated the study area map and its attribute table using satellite images in ArcGIS version 10.4. All authors contributed to the data interpretation and discussion of the manuscript.

Funding: This research was funded by the Ministry of Earth Sciences (MoES), Government of India, through the project 'Cryosphere and Climate' under the 'Polar Sciences and Cryosphere Research (PACER)' scheme.

Acknowledgments: We thank the Director ESSO-National Centre for Polar and Ocean Research for encouragement and Ministry of Earth Sciences for financial support through the project PACER-Cryosphere and Climate. The authors also wish to thank BL Redkar and Ashish Painginkar for assistance with laboratory analysis. The first author would like to thank Rasik Ravindra for encouragement and Runa Antony, K. Mahalinganathan, Rahul Dey, and Sunil Oulkar for their valuable comments. This is NCPOR contribution J-40/2019-20. 
Conflicts of Interest: The authors declare that they have no conflict of interest.

\section{References}

1. AGRIS. Available online: http://agris.fao.org (accessed on 16 July 2018).

2. Bolch, T.; Kulkarni, A.; Kaab, A.; Huggel, C.; Paul, F.; Cogley, J.G.; Frey, H.; Kargel, J.S.; Fujita, K.; Scheel, M.; et al. The State and Fate of Himalayan Glaciers. Science 2012, 336, 310-314. [CrossRef] [PubMed]

3. Immerzeel, W.W.; van Beek, L.P.H.; Bierkens, M.F.P. Climate Change Will Affect the Asian Water Towers. Science 2010, 328, 1382-1385. [CrossRef] [PubMed]

4. Kaser, G.; Grosshauser, M.; Marzeion, B. Contribution potential of glaciers to water availability in different climate regimes. Proc. Natl. Acad. Sci. USA 2010, 107, 20223-20227. [CrossRef] [PubMed]

5. Milner, A.M.; Khamis, K.; Battin, T.J.; Brittain, J.E.; Barrand, N.E.; Fureder, L.; Cauvy-Fraunie, S.; Gislason, G.M.; Jacobsen, D.; Hannah, D.M.; et al. Glacier shrinkage driving global changes in downstream systems. Proc. Natl. Acad. Sci. USA 2017, 114, 9770-9778. [CrossRef]

6. Bookhagen, B.; Burbank, D.W. Topography, relief, and TRMM-derived rainfall variations along the Himalaya (vol 33, art no L08405, 2006). Geophys. Res. Lett. 2006, 33. [CrossRef]

7. Bhambri, R.; Bolch, T. Glacier mapping: A review with special reference to the Indian Himalayas. Prog. Phys. Geogr. 2009, 33, 672-704. [CrossRef]

8. Casper, J.K. Global Warming Cycles: Ice Ages and Glacial Retreat; Infobase Publishing: New York City, NY, USA, 2010.

9. Parry, M.; Parry, M.L.; Canziani, O.; Palutikof, J.; Van der Linden, P.; Hanson, C. Climate Change 2007-Impacts, Adaptation and Vulnerability: Working Group II Contribution to the Fourth Assessment Report of the IPCC; Cambridge University Press: Cambridge, MA, USA, 2007; Volume 4.

10. Craig, H. Isotopic Variations in Meteoric Waters. Science 1961, 133, 1702-1703. [CrossRef]

11. Rahaman, W.; Thamban, M.; Laluraj, C.J.T.H. Twentieth-century sea ice variability in the Weddell Sea and its effect on moisture transport: Evidence from a coastal East Antarctic ice core record. Holocene 2016, 26, 338-349. [CrossRef]

12. Ahluwalia, R.S.; Rai, S.P.; Jain, S.K.; Kumar, B.; Dobhal, D.P. Assessment of snowmelt runoff modelling and isotope analysis: A case study from the western Himalaya, India. Ann. Glaciol. 2013, 54, 299-304. [CrossRef]

13. Jeelani, G.; Kumar, U.S.; Kumar, B. Variation of delta O-18 and delta D in precipitation and stream waters across the Kashmir Himalaya (India) to distinguish and estimate the seasonal sources of stream flow. J. Hydrol. 2013, 481, 157-165. [CrossRef]

14. Jeelani, G.; Shah, R.A.; Fryar, A.E.; Deshpande, R.D.; Mukherjee, A.; Perrin, J. Hydrological processes in glacierized high-altitude basins of the western Himalayas. Hydrogeol. J. 2018, 26, 615-628. [CrossRef]

15. Jeelani, G.; Shah, R.A.; Jacob, N.; Deshpande, R.D. Estimation of snow and glacier melt contribution to Liddar stream in a mountainous catchment, western Himalaya: An isotopic approach. Isot. Environ. Health Stud. 2017, 53, 18-35. [CrossRef] [PubMed]

16. Kumar, A.; Tiwari, S.K.; Verma, A.; Gupta, A.K. Tracing isotopic signatures $(\delta \mathrm{D}$ and $\delta 18 \mathrm{O})$ in precipitation and glacier melt over Chorabari Glacier-Hydroclimatic inferences for the Upper Ganga Basin (UGB), Garhwal Himalaya. J. Hydrol. Reg. Stud. 2018, 15, 68-89. [CrossRef]

17. Laskar, A.H.; Bhattacharya, S.K.; Rao, D.K.; Jani, R.A.; Gandhi, N. Seasonal variation in stable isotope compositions of waters from a Himalayan river: Estimation of glacier melt contribution. Hydrol. Process. 2018, 32, 3866-3880. [CrossRef]

18. Nijampurkar, V.N.; Rao, D.K. Accumulation and Flow-Rates of Ice On Chhota Shigri Glacier, Central Himalaya, Using Radio Active and Stable Isotopes. J. Glaciol. 1992, 38, 43-50. [CrossRef]

19. Rai, S.P.; Thayyen, R.J.; Purushothaman, P.; Kumar, B. Isotopic characteristics of cryospheric waters in parts of Western Himalayas, India. Environ. Earth Sci. 2016, 75, 9. [CrossRef]

20. Verma, A.; Kumar, A.; Gupta, A.K.; Tiwari, S.K.; Bhambri, R.; Naithani, S. Hydroclimatic significance of stable isotopes in precipitation from glaciers of Garhwal Himalaya, Upper Ganga Basin (UGB), India. Hydrol. Process. 2018, 32, 1874-1893. [CrossRef]

21. Shi, M.; Wang, S.; Argiriou, A.A.; Zhang, M.; Guo, R.; Jiao, R.; Kong, J.; Zhang, Y.; Qiu, X.; Zhou, S. Stable Isotope Composition in Surface Water in the Upper Yellow River in Northwest China. Water 2019, 11, 967. [CrossRef] 
22. Kurita, N.; Sugimoto, A.; Fujii, Y.; Fukazawa, T.; Makarov, V.N.; Watanabe, O.; Ichiyanagi, K.; Numaguti, A.; Yoshida, N. Isotopic composition and origin of snow over Siberia. J. Geophys. Res. Atmos. 2005, 110. [CrossRef]

23. Suzuki, K.; Konohira, E.; Yamazaki, Y.; Kubota, J.; Ohata, T.; Vuglinsky, V. Transport of organic carbon from the Mogot Experimental Watershed in the southern mountainous taiga of eastern Siberia. Hydrol. Res. 2006, 37, 303-312. [CrossRef]

24. Owen, L.A.; Bailey, R.M.; Rhodes, E.J.; Mitchell, W.A.; Coxon, P. Style and timing of glaciation in the Lahul Himalaya, northern India: A framework for reconstructing late Quaternary palaeoclimatic change in the western Himalayas. J. Quat. Sci. 1997, 12, 83-109. [CrossRef]

25. Kumar, V.; Singh, P.; Singh, V. Snow and glacier melt contribution in the Beas River at Pandoh Dam, Himachal Pradesh, India. Hydrol. Sci. J. 2007, 52, 376-388. [CrossRef]

26. Singh, P.; Jain, S.K. Snow and glacier melt in the Satluj River at Bhakra Dam in the western Himalayan region. Hydrol. Sci. J. 2002, 47, 93-106. [CrossRef]

27. Singh, P.; Jain, S.K.; Kumar, N. Estimation of snow and glacier-melt contribution to the Chenab River, Western Himalaya. Mt. Res. Dev. 1997, 17, 49-56. [CrossRef]

28. Maurya, A.S.; Shah, M.; Deshpande, R.D.; Bhardwaj, R.M.; Prasad, A.; Gupta, S.K. Hydrograph separation and precipitation source identification using stable water isotopes and conductivity: River Ganga at Himalayan foothills. Hydrol. Process. 2011, 25, 1521-1530. [CrossRef]

29. Burns, D.A. Stormflow-hydrograph separation based on isotopes: The thrill is gone-What's next? Hydrol. Process. 2002, 16, 1515-1517. [CrossRef]

30. Unnikrishna, P.V.; McDonnell, J.J.; Kendall, C. Isotope variations in a Sierra Nevada snowpack and their relation to meltwater. J. Hydrol. 2002, 260, 38-57. [CrossRef]

31. Rai, S.P.; Singh, D.; Jacob, N.; Rawat, Y.S.; Arora, M.; Kumar, B. Identifying contribution of snowmelt and glacier melt to the Bhagirathi River (Upper Ganga) near snout of the Gangotri Glacier using environmental isotopes. Catena 2019, 173, 339-351. [CrossRef]

32. Kumar, N.; Ramanathan, A.; Keesari, T.; Chidambaram, S.; Ranjan, S.; Soheb, M.; Tranter, M. Tracer-based estimation of temporal variation of water sources: An insight from supra- and subglacial environments. Hydrol. Sci. J. 2018, 63, 1717-1732. [CrossRef]

33. Singh, A.T.; Laluraj, C.M.; Sharma, P.; Patel, L.K.; Thamban, M. Export fluxes of geochemical solutes in the meltwater stream of Sutri Dhaka Glacier, Chandra basin, Western Himalaya. Environ. Monit. Assess. 2017, 189. [CrossRef]

34. Pratap, B.; Sharma, P.; Patel, L.; Singh, A.T.; Gaddam, V.K.; Oulkar, S.; Thamban, M. Reconciling High Glacier Surface Melting in Summer with Air Temperature in the Semi-Arid Zone of Western Himalaya. Water 2019, 11, 1561. [CrossRef]

35. Sharma, P.; Patel, L.K.; Ravindra, R.; Singh, A.; Mahalinganathan, K.; Thamban, M. Role of debris cover to control specific ablation of adjoining Batal and Sutri Dhaka glaciers in Chandra Basin (Himachal Pradesh) during peak ablation season. J. Earth Syst. Sci. 2016, 125, 459-473. [CrossRef]

36. Azam, M.F.; Wagnon, P.; Vincent, C.; Ramanathan, A.; Favier, V.; Mandal, A.; Pottakkal, J.G. Processes governing the mass balance of Chhota Shigri Glacier (western Himalaya, India) assessed by point-scale surface energy balance measurements. Cryosphere 2014, 8, 2195-2217. [CrossRef]

37. Pradesh, I. Central Ground Water Board. Available online: http://cgwb.gov.in/District_Profile/HP/Lahul\% 20Spiti.pdf (accessed on 25 October 2019).

38. Srivastava, P.K.; Han, D.; Rico-Ramirez, M.A.; Islam, T. Sensitivity and uncertainty analysis of mesoscale model downscaled hydro-meteorological variables for discharge prediction. Hydrol. Process. 2014, 28, 4419-4432. [CrossRef]

39. Chakraborty, S.; Sinha, N.; Chattopadhyay, R.; Sengupta, S.; Mohan, P.M.; Datye, A. Atmospheric controls on the precipitation isotopes over the Andaman Islands, Bay of Bengal. Sci. Rep. 2016, 6. [CrossRef]

40. Coplen, T.; De Bièvre, P.; Krouse, H.; Vocke, R., Jr.; Gröning, M.; Rozanski, K. Ratios for light-element isotopes standardized for better interlaboratory comparison. Eos Trans. Am. Geophys. Union 1996, 77, 255. [CrossRef]

41. Dansgaard, W. Stable isotopes in precipitation. Tellus 1964, 16, 436-468. [CrossRef]

42. Taylor, S.; Feng, X.H.; Williams, M.; McNamara, J. How isotopic fractionation of snowmelt affects hydrograph separation. Hydrol. Process. 2002, 16, 3683-3690. [CrossRef] 
43. He, Y.; Pang, H.; Theakstone, W.; Zhang, D.; Lu, A.; Song, B.; Yuan, L.; Ning, B. Spatial and temporal variations of oxygen isotopes in snowpacks and glacial runoff in different types of glacial area in western China. Ann. Glaciol. 2006, 43, 269-274. [CrossRef]

44. Gibson, J.J.; Price, J.S.; Aravena, R.; Fitzgerald, D.F.; Maloney, D. Runoff generation in a hypermaritime bog-forest upland. Hydrol. Process. 2000, 14, 2711-2730. [CrossRef]

45. Throckmorton, H.M.; Newman, B.D.; Heikoop, J.M.; Perkins, G.B.; Feng, X.; Graham, D.E.; O’Malley, D.; Vesselinov, V.V.; Young, J.; Wullschleger, S.D.; et al. Active layer hydrology in an arctic tundra ecosystem: Quantifying water sources and cycling using water stable isotopes. Hydrol. Process. 2016, 30, 4972-4986. [CrossRef]

46. Rao, S.; Rao, M.; Ramasastri, K.; Singh, R. A study of sedimentation in Chenab basin in western Himalayas. Hydrol. Res. 1997, 28, 201-216. [CrossRef]

47. Østrem, G.; Brugman, M. Glacier Mass Balance Measurement Techniques: A Manual for Field and Office Work. Available online: https://wgms.ch/downloads/Oestrem_Brugman_GlacierMassBalanceMeasurements_1991. pdf (accessed on 25 October 2019).

48. Mernild, S.H.; Pelto, M.; Malmros, J.K.; Yde, J.C.; Knudsen, N.T.; Hanna, E. Identification of snow ablation rate, ELA, AAR and net mass balance using transient snowline variations on two Arctic glaciers. J. Glaciol. 2013, 59, 649-659. [CrossRef]

49. Draxler, R.R.; Rolph, G.D. Hysplit (hybrid single-particle lagrangian integrated trajectory) model access via NOAA ARL ready website. Silver Spring MD 2011, 8, 26.

50. Stein, A.F.; Draxler, R.R.; Rolph, G.D.; Stunder, B.J.B.; Cohen, M.D.; Ngan, F. Noaa's Hysplit Atmospheric Transport And Dispersion Modeling System. Bull. Am. Meteorol. Soc. 2015, 96, 2059-2077. [CrossRef]

51. Wallace, J.M.; Hobbs, P.V. Atmospheric Science: An Introductory Survey; Elsevier: Amsterdam, The Netherlands, 2006; Volume 92.

52. Wang, Y.; Zhang, X.; Draxler, R.R. TrajStat: GIS-based software that uses various trajectory statistical analysis methods to identify potential sources from long-term air pollution measurement data. Environ. Model. Softw. 2009, 24, 938-939. [CrossRef]

53. Kraaijenbrink, P.D.A.; Bierkens, M.F.P.; Lutz, A.F.; Immerzeel, W.W. Impact of a global temperature rise of 1.5 degrees Celsius on Asia's glaciers. Nature 2017, 549, 257-260. [CrossRef]

54. Zhou, S.; Nakawo, M.; Hashimoto, S.; Sakai, A. The effect of refreezing on the isotopic composition of melting snowpack. Hydrol. Process. 2008, 22, 873-882. [CrossRef]

55. Stichler, W.; Schotterer, U.; Frohlich, K.; Ginot, P.; Kull, C.; Gaggeler, H.; Pouyaud, B. Influence of sublimation on stable isotope records recovered from high-altitude glaciers in the tropical Andes. J. Geophys. Res. Atmos. 2001, 106, 22613-22620. [CrossRef]

56. Rozanski, K.; Araguás-Araguás, L.; Gonfiantini, R. Isotopic patterns in modern global precipitation. Clim. Chang. Cont. Isot. Rec. 1993, 78, 1-36.

57. Wu, J.-K.; Ding, Y.-J.; Yang, J.-H.; Liu, S.-W.; Zhou, J.-X.; Qin, X. Spatial variation of stable isotopes in different waters during melt season in the Laohugou Glacial Catchment, Shule River basin. J. Mt. Sci. 2016, 13, 1453-1463. [CrossRef]

58. Jeelani, G.; Deshpande, R.D.; Shah, R.A.; Hassan, W. Influence of southwest monsoons in the Kashmir Valley, western Himalayas. Isot. Environ. Health Stud. 2017, 53, 400-412. [CrossRef] [PubMed]

59. Zhou, S.; Wang, Z.; Joswiak, D.R. From precipitation to runoff: Stable isotopic fractionation effect of glacier melting on a catchment scale. Hydrol. Process. 2014, 28, 3341-3349. [CrossRef]

60. Lone, S.A.; Jeelani, G.; Deshpande, R.D.; Mukherjee, A. Stable isotope (delta O-18 and delta D) dynamics of precipitation in a high altitude Himalayan cold desert and its surroundings in Indus river basin, Ladakh. Atmos. Res. 2019, 221, 46-57. [CrossRef]

61. Kumar, A.; Gokhale, A.A.; Shukla, T.; Dobhal, D.P. Hydroclimatic influence on particle size distribution of suspended sediments evacuated from debris-covered Chorabari Glacier, upper Mandakini catchment, central Himalaya. Geomorphology 2016, 265, 45-67. [CrossRef]

62. Khan, A.A.; Pant, N.C.; Sarkar, A.; Tandon, S.K.; Thamban, M.; Mahalinganathan, K. The Himalayan cryosphere: A critical assessment and evaluation of glacial melt fraction in the Bhagirathi basin. Geosci. Front. 2017, 8, 107-115. [CrossRef]

63. Pfahl, S.; Sodemann, H. What controls deuterium excess in global precipitation? Clim. Past 2014, 10, 771-781. [CrossRef] 
64. Bazemore, D.E.; Eshleman, K.N.; Hollenbeck, K.J. The role of soil water in stormflow generation in a forested headwater catchment: Synthesis of natural tracer and hydrometric evidence. J. Hydrol. 1994, 162, 47-75. [CrossRef]

65. Genereux, D. Quantifying uncertainty in tracer-based hydrograph separations. Water Resour. Res. 1998, 34, 915-919. [CrossRef]

66. Funk, M.; Morelli, R.; Stahel, W. Mass balance of Griesgletscher 1961-1994: Different methods of determination. With 10 figures. Z. Gletsch. Glazialgeol. 1997, 33, 41-56.

67. Jansson, P. Effect of uncertainties in measured variables on the calculated mass balance of Storglaciaren. Geogr. Ann. Ser. A Phys. Geogr. 1999, 81A, 633-642. [CrossRef]

(C) 2019 by the authors. Licensee MDPI, Basel, Switzerland. This article is an open access article distributed under the terms and conditions of the Creative Commons Attribution (CC BY) license (http://creativecommons.org/licenses/by/4.0/). 